\title{
James Henry Greathead and the London Underground
}

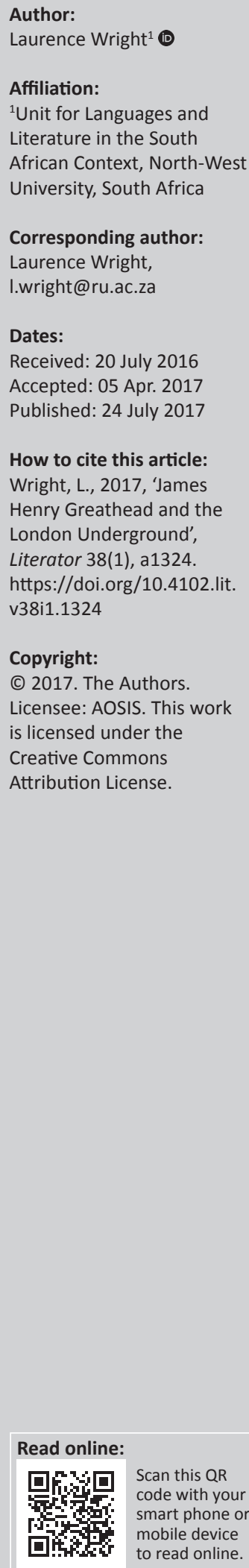

This article investigates the origins and early history of the device known as the 'Greathead Shield', an important innovation in Victorian engineering crucial to constructing the London Underground. The aim is to explore the basis on which, many years later, a South African engineer, James Henry Greathead, was accorded prominent public acknowledgment, in the form of a statue, for 'inventing' the Shield. From a cultural studies perspective, how is the meaning of 'invention' to be understood, given that several other brilliant engineers were involved? The question is adjudicated using the notion of cultural 'extelligence', seen in relation to several contemporary and historical accounts, including Greathead's own record of his achievements in the proceedings of the Institution of Civil Engineers and presented in The City and South London Railway (1896), edited by James Forrest. The paper was first delivered at the conference on 'Novelty and Innovation in the Nineteenth Century' held at the North-West University in May 2016.

James Henry Greathead en die Londense Moltrein. Die artikel ondersoek die oorsprong en vroeë geskiedenis van die toestel genaamd die 'Greathead Skild', 'n belangrike nuwigheid in Viktoriaanse ingenieurwetenskap, wat van deurslaggewende belang was in die konstruksie van die Londense Moltrein. Die doel is om die basis te ontleed waarop, baie jare later, ' $n$ SuidAfrikaanse ingenieur wye openbare erkenning in die vorm van 'n standbeeld vir die 'ontwerp' van die Skild geniet het. Uit die perspektief van kulturele studies beskou, hoe moet ons uitvinding verstaan, gegewe dat ander briljante ingenieurs ook betrokke was? Hierdie vraag word ontleed met die gebruik van die konsep 'extelligence' (Stewart and Cohen 1997), in samehang met ander kontemporêre en geskiedkundige weergawes, insluitend Greathead se eie rekord van sy prestasies in die verrigtinge van die Instituut van Siviele Ingenieurs en voorgelê in The City and South London Railway (1896), onder redaksie van James Forrest. Hierdie artikel is die eerste keer as referaat aangebied by die konferensie oor 'Nuuthede en Innovasie in die Negentiende Eeu' aan die Noordwes-Universiteit, Mei 2016.

'Well [done], old mole. Canst work i' th' earth so fast?' (Hamlet 1.5)

\section{Background}

Smoking on London Underground trains was banned in 1984 and on all Underground stations in 1985. Tragically, some passengers continued to ignore the danger, lighting up on the escalators as they left the system. On the night of 18th November 1987, a lighted match, dropped on an old wooden escalator at King's Cross Underground Station, caused a massive fire which resulted in the deaths of 31 people. Following this disaster, not only was the smoking ban throughout the London Underground reinforced, but the ensuing safety investigation recommended wideranging safety modifications across the system (Fennell 1988). Among these was a requirement for improved ventilation at Bank Station, the station named for its proximity to the Bank of England in Threadneedle Street. Bank Station lies beneath Bank Junction, an intersection where nine roads converge in the heart of London's old financial district. The new ventilation shaft proposed for this famous intersection had to be large, about the size of a London double-decker bus (Tugnutt n.d.), and a bold decision was taken to hide the shaft in plain sight by disguising it as a plinth for a statue standing in the middle of Cornhill, the street running along the right-hand side of the Royal Exchange.

The site was of considerable symbolic importance. The original Royal Exchange building, opened in 1571 by Queen Elizabeth I, was the first dedicated commercial building to be erected in London. The current one, opened in 1844, the third on the site, hosts trendy boutiques, cafes 


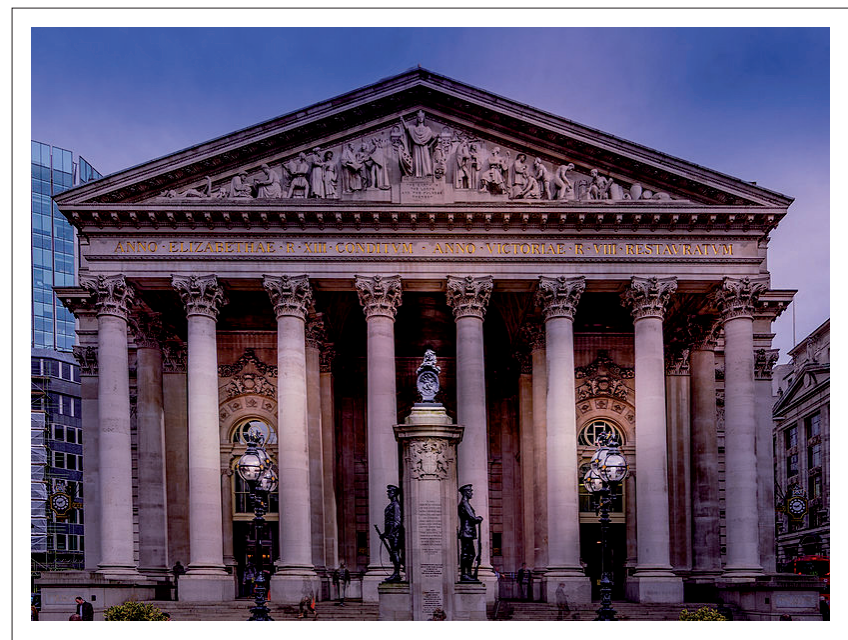

Source: Wikipedia, n.d.a, 'Royal Exchange, London, UK' viewed 14 July 2016, from https:// commons. wikimedia.org/w/index. php?curid=35681312

FIGURE 1: The Royal Exchange.

and restaurants, rather than high-flying financial transactions, but it retains symbolic importance because it is from the steps of the Royal Exchange that Royal Proclamations, such as the dissolution of Parliament, are announced by a herald or the town crier (see Figure 1). Topographically, Bank Junction stands on raised ground adjacent to the site of the ancient ford across the River Thames, which led to the founding of the settlement of Londinium by the Romans around AD 43. As such, the congested road layout at Bank Junction, which has prompted plans to rid the intersection of all vehicular traffic other than buses (see City of London n.d.), stretches back into the city's mediaeval past. Mindful that an imposing equestrian statue of the Duke of Wellington, celebrating his historic victory at Waterloo, graces the intersection of Threadneedle Street and Cornhill, projecting into Bank Junction like the prow of a ship, and that directly behind the statue, in front of the Royal Exchange, is situated the city's memorial to Londoners who died in the two World Wars, the subject for the proposed statue in Cornhill had to be both culturally weighty and symbolically appropriate. If the heart of London is anywhere, this is it.

A first suggestion, celebrating the Royal Exchange as the fons et origo of today's regulated stock market, ${ }^{1}$ was a symbolic sculptural grouping of Bull, Bear and Stag. A preliminary mock-up was not well received. According to the conservation officer for the London Corporation at the time, Tony Tugnutt, it looked like 'something out of Walt Disney's studio'. Tugnutt and an unnamed friend, who was something of a railway buff, came up with another suggestion: a statue of James Henry Greathead (1844-1896), the South African-born civil engineer who developed the technology known as the Greathead Shield, which enabled construction of the London Underground's deep tunnels (Tugnutt n.d.). Greathead's achievements had always been known and acknowledged in engineering circles, but there was no public recognition,

\footnotetext{
1. Historically, open-air mercantile activity took its rise in nearby Exchange Alley, also known as 'Change' Alley. Commodities and shares were also traded in local coffee houses until Thomas Gresham founded the Royal Exchange in 1565.
}

aside from an English Heritage blue plaque on his former home in Barnes. ${ }^{2}$ The Tugnutt proposal met with approval, and the eminent figurative sculptor James Butler, RA, MBE, was commissioned to make the statue $^{3}$ which, again according to Tony Tugnutt, cost the London Underground 'an arm and a leg'. The statue was unveiled by the Lord Mayor of London in 1994, almost a hundred years after Greathead's death (see Figure 2a and 2b).

The inscription on the plinth reads:

\section{J.H. GREATHEAD \\ CHIEF ENGINEER \\ CITY AND SOUTH LONDON RAILWAY
THAT MADE POSSIBLE THE CUTTING
OF THE TUNNELS OF LONDON'S DEEP LEVEL TUBE SYSTEM \\ INVENTOR OF THE TRAVELLING SHIELD}

The inscription announces the claim this article sets out to evaluate. Was Greathead the inventor of the Greathead Shield? What does it mean to 'invent'? Many others were involved, conceptually and practically, in the innovations which made the Greathead Shield possible. Progress was cumulative, the result of engineering failures and collaborations stretching back over several generations, on different continents and over many years, as is usually the case. Rather than to challenge Greathead's distinction, the aim here is to arrive at a better understanding of what he achieved, and how it was that he, rather than any of his remarkable collaborators, came to be honoured with a public statue. In short, why, roughly a hundred years after his death, did London decide to honour James Henry Greathead with so public an accolade?

\section{Origins and early life}

In dress and deportment, the Greathead statue in Cornhill is a far cry from more usual portrayals of distinguished Victorian gentlemen resting on their laurels. This is an engineer at work. His appearance is somewhat foreign because the sculptor wanted to pay tribute to his origins. James Henry Greathead was born in Grahamstown in the Cape Colony on 6 August 1844 (see Figure 3). His grandfather, also named James Henry Greathead (1796-1830), was a landsurveyor by profession, leader of the Greathead Party of 1820 Settlers who arrived in Algoa Bay aboard the 'Kennersley Castle' on 29th April of that year (Nash 1987). He was 24. Greathead's party, one of five on the ship, comprised 20 people, mainly from Worcestershire in the West Midlands of England. ${ }^{4}$ From Algoa Bay they travelled to the Albany

\footnotetext{
2.He lived at 3, St. Mary's Grove, Barnes, from 1885 to 1889 . Greathead died at Streatham at the early age of 52 , in 1896.

3.Among Butler's more notable commissions have been the current British Great Seal of the Realm; the Royal Jubilee Presentation Coin, 1952-2002; the Croix Rouge Farm of the Realm, the Royal Memorial, Château-Thiery, France; President Jomo Kenyatta, Nairobi, Kenya President Kwame Nkrumah of Ghana at Kabwe, Zambia; Monument to the Freedom Fighters of Zambia, Lusaka, Zambia; Soldier, The Green Howards, D-Day Memorial, Crépon, Normandy, France; King Richard III, Castle Gardens, Leicester; Thomas Cook (of tourism fame) outside Leicester Railway Station; and many others.
}

4.The Bradshaw, Holder, Philipps and Southey parties were the others. 


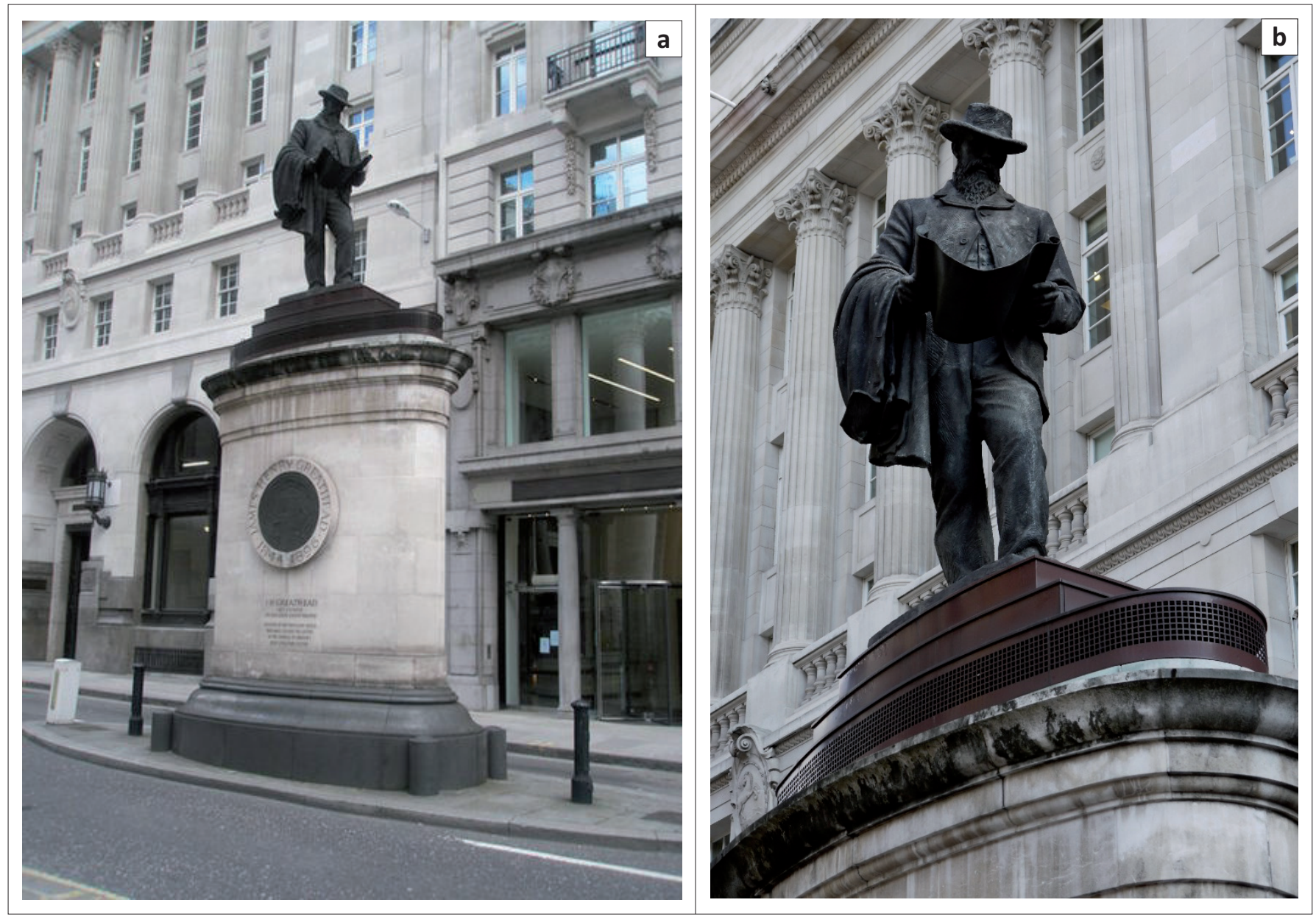

Source: (a) Wikipedia, n.d.b, 'Statue of James Henry Greathead outside The Royal Exchange Surprisingly only erected in 1994', viewed 14 July 2016, from https://en.wikipedia.org/wiki/ File\%3AStatue_of_James_Henry_Greathead_outside_The_Royal_Exchange_-_geograph.org.uk_-_887035.jpg; (b) Wikipedia, n.d.c, 'Close-up image of the J. H. Greathead statue', viewed 14 July 2016, from https://commons.wikimedia.org/w/index.php?curid=30753052

FIGURE 2: The Greathead Statue: (a) the traffic island in Cornmarket and (b) the underground ventilation outlets visible on the third tier below the statue.

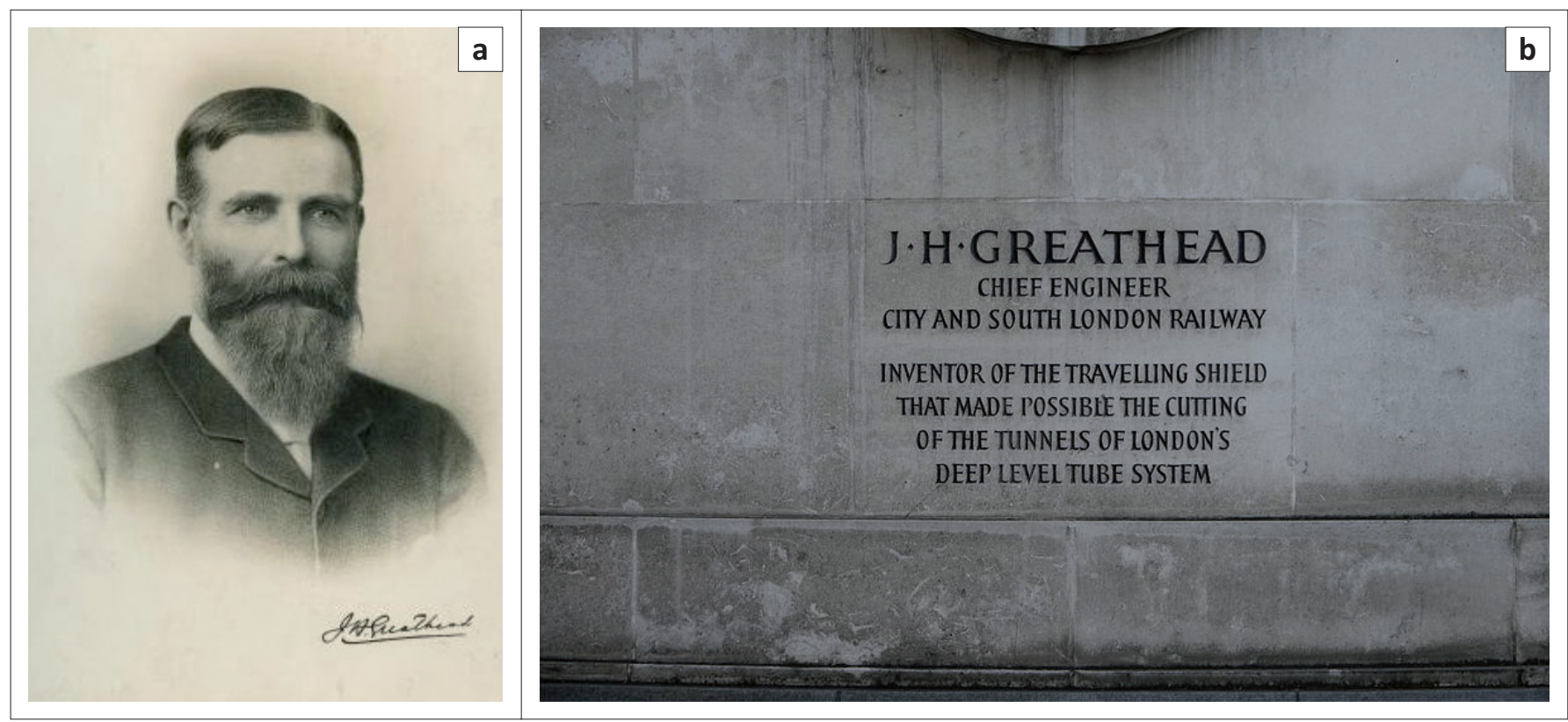

Source: Wikipedia, n.d.d, 'James Henry Greathead (1844-1896), civil and railway engineer', viewed 14 July 2016, from https://commons.wikimedia.org/wiki/File:James_Henry_Greathead.png. Wikipedia, n.d.e, 'Inscription on the plinth of J. H. Greathead', viewed 14 July 2016, from https://commons.wikimedia.org/w/index.php?curid=30753050

FIGURE 3: (a) James Henry Greathead and (b) the inscription below his statue. 
district on the frontier of the Cape Colony, where they were apportioned land between Bathurst and Grahamstown, on the Bush River, a tributary of the Kowie. They named the farm 'Tivia Dale' (Nash 1987). In time, largely because the Zuurveld was not the agricultural paradise the settlers had been lead to expect, land allocations being too small to be agriculturally viable in such dry and rugged terrain, the Greatheads, like many of the 1820 Settlers, moved into Grahamstown to make a living by other means. Greathead's eldest son, also called James Henry Greathead (1819-1864), who had been a one-year-old baby when the family emigrated, grew up there and in due course married Julia Wright (1824-1908), daughter of a settler family from Turvey's Party at Sunday's River. He became a successful businessman, with commercial interests as far afield as Cradock and Aliwal North. ${ }^{5}$ The two had 13 children, the second of whom was named, with immaculate consistency, James Henry Greathead - the boy who was to become the future civil engineer. He was educated in Grahamstown at St. Andrew's College from 1855 until 1859, when the whole family travelled to Britain for a visit of some 4 years. Young James Henry Greathead completed his schooling at the Westbourne Collegiate School in London (1859-1863). ${ }^{6}$ When his family returned to Grahamstown, Greathead entered a 3-year pupillage with a leading civil engineer, Peter W. Barlow, who was to become, among other engineering proclivities, an important pioneer in modern, large-scale soft ground tunnelling.?

\section{A tale of three tunnels}

The engineering history leading to Greathead's being honoured is complex, but at its heart is the story of the first three tunnels under the River Thames: Marc Brunel's Thames Tunnel, which was the world's first underwater tunnel (1843); the Tower Subway (1870), engineered by Peter W. Barlow and James Henry Greathead, which carried (briefly) the world's first underground railway; and The City and South London Railway (1890), the world's first commercially successful electrified underground 'tube' railway, constructed using the Greathead Shield. So many 'firsts'!

Why the Thames and not some other urban waterway? Progress in subaqueous tunnel engineering centred on the Thames because the river was the main transport artery for Britain's growing empire, an empire whose commercial

5 James Henry Greathead, Jr the engineer's father, became senior partner in the firm of Greathead and Bate, which he formed with his brother-in-law, Frederick Calde of Greathead and Bate, which he formed with his brother-in-law, Frederick Calder Bate. The business flourished in Cradock and Aliwal North until the economic crash
of 1870 . He became a member of the Legislative Assembly in 1858, but resigned in 1860 to visit England with his large family. Four years later, in 1864, they returned to Grahamstown, young James Henry Greathead remaining in London to begin his engineering career. In Grahamstown, the family settled in a cottage called 'Fai Lawn', on an 11-acre farm on the fringes of Grahamstown, as it then was. Greathead developed the cottage into a bow-fronted, double storied house which today accommodates the Primary Division of St Andrew's Preparatory School.

6.Westbourne Collegiate School was a private boys' school, founded in 1847, and associated with King's College, London. In 1879, it was located at Powis House, Colville Road, Kensington, and had some 50 boarders as well as day pupils.

7.Peter William Barlow (1809-1885) was the son of Professor Peter Barlow (17761862), a distinguished mathematician and engineer at the Royal Military Academy at Woolwich. His brother, William Henry Barlow (1812-1902) was a noted railway engineer, and his son, Peter W. Barlow Jnr., assisted him (and Greathead) on the Tower Subway construction. tentacles had been stretching across 'the great globe itself' since Shakespeare's time (1987; see The Tempest 4.1.153). Law (1845-1846:2) captured the river's contemporary significance when, somewhat grandiloquently, he described the Thames as 'flowing through the centre of the great metropolis of the world'. In the late 18th century, at the height of the Industrial Revolution, the stretch of river between London Bridge and Limehouse known as the Pool of London was becoming impossibly congested. Even though large off-river docks were gradually built downstream to relieve the pressure, commercial London still sprawled on either side of the river, and ships under sail did not take kindly to their course constantly being disrupted by barges crossing the river (Law 1845-1846:2). Regulatory constraints were imposed. Moreover, goods arriving at docks on the north bank of the Thames but destined for businesses south of the river had to pay a toll to cross London Bridge, at the western end of the Pool of London. The bottlenecks, delays and extra expenses affected business. Although in time additional bridges were built upstream - in 1851 there were eight altogether, with a further two planned (Drew 1852) - one obvious solution was to tunnel under the river.

Historically, engineers had shied away from subaqueous tunnelling because the dangers of water incursion made it even more dangerous than ordinary soft ground tunnelling. Hard rock tunnelling, on the other hand, was well established, its roots going back to antiquity and associated mainly with mining. Ancient hard rock tunnelling employed either fire or brute strength. The former involved fire-setting to heat the rock, followed by rapid cooling using cold water, to shatter it. The latter was the equivalent of today's hammer and chisel. If the overburden was relatively sound, with few folds, discontinuities or fractures, history shows that hard rock tunnelling, though challenging, was likely to be successful. ${ }^{8}$ The 19th century, with its much-improved technology, would see notable achievements in hard rock tunnelling, most notably the Mont Cenis Tunnel through the Alps (1857-1871), which established rail transportation between France and Italy, and the St. Gotthard Tunnel (18721882), which pioneered the large-scale use of dynamite in tunnel construction (Byrn 1900). But little of this engineering 'extelligence' ${ }^{9}$ in large-scale hard ground tunnelling, accumulating gradually over the years, was relevant to the specific difficulties of subaqueous tunnelling.

Soft ground tunnelling, which was what the Thames project required, was more challenging. The Romans had built fine tunnels supported by masonry arches, using cut-and-cover

\footnotetext{
8.Stone age people in Britain sank shafts to excavate flint for bladed tools. The Aztecs, the Incas, the Babylonians, the Egyptians and the Persians all made tunnels, using the implements available to them: bone, antler, flint and wood among the early humans; then bronze, iron and steel as these technologies developed (Wahlstrom 1973; West 2005).

9.'Extelligence' is a term coined by Stewart and Cohen (1997) to denote the cultural legacy or material reflex of applied human intelligence. Intelligence (mind) allows humans to process freshly the accumulated complexities of culture, or 'extelligence' Extelligence is not simply the documented cultural cecord, but an comprises that record (p. 243). This article, for instance, is an exercise in making cultural sense of the extelligence associated with Greathead, his statue, and the London 'tube'.
} 
methods. An open trench was excavated and then roofed over, an exercise that could hardly be described as tunnelling. Only in the Middle Ages was soft ground tunnelling attempted seriously, and it was later still, in the Early Modern period, that a systematic methodology was adopted..$^{10}$ Stout timber frames, or 'sets', were constructed to support the roof and walls of the cut and reinforced by a lagging of poles and boards outside the frames at danger points wherever soft ground incursion seemed likely. Different national systems of structuring the timbering were adopted across Europe but, whatever the system, the temporary timbering would eventually be replaced by solid masonry arching to complete the permanent tunnel (Vogel 1966). Fundamentally, this remained the accepted technology for soft ground tunnelling at the beginning of the 19th century, when tunnelling under the Thames was first being contemplated seriously.

In 1798, Ralph Dodd, a well-known builder and prolific promoter of engineering schemes, proposed building a tunnel under the Thames from Gravesend to Tilbury, connecting Kent and Essex. The project was under-funded and, worse, unsound from an engineering perspective, according to Charles Clark of the Gravesend Ordinance Office (Clark 1799). Nevertheless, the requisite Act of Parliament was passed (Stat. 39 Geo. 3., c73), and construction commenced. An early account describes how 'the Tunnel had not proceeded far under the bed of the river, when the water broke through in such force as to render its execution no longer feasible' (The Mirror, 22 May 1824:322). This was despite a steam-driven pump and digging machines having been installed in 1801 to address the difficulties. The project was abandoned in 1802. Shortly after this, between 1805 and 1809, a group of Cornish miners, led first by Robert Vaizie and then by Richard Trevithick (of steam engine fame), attempted a tunnel under the river between Rotherhithe and Limehouse, the so-called Thames Archway project. The group's experience lay with hard rock mining. They were initially confident that high-pressure steam pumping technology, as used in the Cornish mines, would be adequate to cope with water incursion (Mather 2004). However, flooding imperilled the vertical shaft at Rotherhithe even before the tunnel itself had been commenced. When the tunnel drive was begun, a steam engine at the bottom of the shaft both powered a pump to extract the water and hauled the muck-waggons out of the drive. Excavation was by hand, the tunnel being protected with timber props, as in traditional mining practice. Having advanced some 950 feet $(290 \mathrm{~m})$, with incessant incursions of ground water, in January 1808 an inrush of sand followed by torrents of water completely flooded the workings. The breach was swiftly covered with clay and the tunnel pumped out, but the same thing happened a month later. This proved to be the coup de grace. Only 117 feet $(36 \mathrm{~m})$ short of its intended length (Trevithick estimated

10.The book to read on early mining and tunnelling is Agricola.'s De Re Metallica, o. On the Nature of Metals', published in Basel in 1556. Agricola was the pen name of the Nature of Metals', published in Basel in 1556. Agricola was the pen name of Georg Bauer (1494-1555). His magnificently illustrated book on mediaeval mining practices in Germany appeared the year after his death, in 1556. Before him, the classical authority had been Pliny the Elder's Historia Naturalis (AD 77-79) (Natura History, transl. D.E. Eicholz, 1962). The first English translation of Agricola, by Henry Hoover (later President of the United States) and his wife, Lou Henry Hoover, a geologist and Latinist, was published in London by subscription in 1912. it would take only 10 or 12 days to finish the drive), the company refused to advance the money required to construct the caisson, which would have allowed Trevithick to pump out the workings. The pilot drive was never completed, and the structure was allowed to collapse (West 2005). This was the first time, but not the last, that idiosyncratic financial judgments would imperil the overall success of tunnels under the Thames. The engineering failure of these initial attempts was a result of employing hard rock technologies where soft ground tunnelling innovations were required. As Mather explains (2004):

ground conditions in the Thames floodplain ... were quite unlike the conditions in the wettest of Cornish mines, where ... as long as you can deal with the quantity of water, the strata will require little assistance to remain upstanding. (p. 151)

\section{The Thames Tunnel}

Enter Marc Isambard Brunel (1769-1849), the French engineer who had arrived in Britain in 1799. Marc Brunel is popularly remembered as the father of Isambard Kingdom Brunel, the world's greatest civil engineer; but he should be better known in his own right, firstly, for inventing the tunnelling shield (Patent No. 4204 of 1818), which revolutionised soft ground tunnelling, and, secondly, for driving the world's first tunnel under a navigable waterway, between Rotherhithe and Wapping on the River Thames (Brunel 1870). Copperthwaite (1906:1) observes that Brunel's patent specification, which is reproduced in Copperthwaite's book, 'covers every subsequent development in the construction and working of tunnel shields'.

When labourers are digging a tunnel in soft conditions, through silt, sand, gravel or mud, stand-up time is obviously critical. This is doubly true of subaqueous tunnelling. How much time is there before the area above the tunnel face, the overburden, collapses, causing the tunnel to flood? A reinforcing frame section must be in place before that collapse can happen. In other words, the protective timber frame of the old mediaeval technology must move forward as the tunnel progresses. Here lay the challenge to Marc Brunel's ingenuity. The story goes that the concept of a tunnelling shield came to him while he was studying the boring action of the so-called 'naval ship-worm', Teredo navalis, 'a marine worm that can penetrate the hardest woods' (Copperthwaite 1906:7), and which caused huge damage to the woodenhulled ships of the day (Beaver 1973:37). From this inspiration, if the anecdote is to be believed, he began developing the tunnelling shield.

The 1818 patent covered two very different concepts. The first, closely related to the shields he actually used to construct the Thames Tunnel, is described below. The second, never built, was a remarkable concept. He named it 'teredo' after the ship-worm that inspired it (Greathead 1896:19). It comprised a 12 foot $(4 \mathrm{~m})$ auger-blade turning in an iron cylinder. Brunel described the machine to the Institution of Civil Engineers as 'an ambulating coffer-dam, travelling horizontally' (Institution of Civil Engineers 1848 [1837], I, 34). 
The blade was to be rotated manually by brute force, while the cylinder was propelled along the line of the tunnel by jacks pressing off the brickwork lining of the preceding section. The idea was in advance of its time. Practically speaking, mere muscle-power could never have turned the rotating blade with sufficient force to cut into clay or silt. Greatly enhanced motive power would have been required to operationalise the idea. Nevertheless, in principle Brunel had envisaged a tunnelling machine much like those in use today. His was a brilliant concept awaiting development and implementation by others.

In practice, to build his Thames Tunnel Brunel resorted to a more mundane, rectangular profile for his novel machine, with no connection whatever to the ship-worm idea, and much closer in inspiration to mediaeval practice. Brunel's shield was massive, consisting of 12 connected frames, made of cast- and wrought-iron, placed side-by-side against the tunnel face, and protected on the sides, top and bottom, by heavy metal sheets. The frames themselves weighed more than 7 tons apiece. Each frame was 22 feet $(7 \mathrm{~m})$ high and 3 feet $(0.9 \mathrm{~m})$ wide, divided into three work spaces, one above the other, where diggers could work in safety. The 12 frames, side-by-side, thus accommodated 36 men digging at the tunnel face, and the shield protected an operational area 9 feet $(3 \mathrm{~m})$ deep in front of each freshly completed section of tunnel lining. A movable wall of short sturdy planks separated the cells from the working face. A workman in his cell would take out one plank and dig out 3 or 4 inches of material, replace the plank and force it back against the receding face by means of two screw jacks. Then he would tackle the next plank. Eventually, when the entire face had been reduced by 3 or 4 inches, the frame would have its 'feet' moved forward, and then the frame itself would be eased into the space created, using jacks pushing off the brick casing of the tunnel built behind it. In practice, alternate frames would be moved forward so that the shield's progress was staggered but coherent (Copperthwaite 1906; Law 1845-1846) (see Figure 4a and 4b).

'Ponderous' describes all aspects of Brunel's project. After lowering the shield, piece by piece, down the shaft on the Rotherhithe side and then assembling it, the slow traverse under the Thames commenced on 25 November 1825. And slow it was, only 8 feet -12 feet a week (about $3 m-4 m$ ). Men fell ill from the sewage-laden water seeping into the tunnel. In 1826, the resident engineer, William Armstrong, succumbed to illness, and was replaced by Brunel's son, Isambard Kingdom Brunel. The enterprise was hazardous. The tunnel flooded in May 1827, after driving 549 feet $(167 \mathrm{~m})$ under the Thames, and again in January 1828, when six men died. The younger Brunel on this occasion was fortunate to escape with his life. The project fell into financial difficulties and was eventually walled-off just behind the shield and abandoned for 7 long years. In 1834, Marc Brunel succeeded in raising more finance, the old rusted shield was replaced by a new, improved one and, after four more floods, some fires, explosions of methane and hydrogen sulphide gas, and another $5 \frac{1}{2} 2$ years of relentless effort, the tunnel was completed in 1843. It had taken 19 years. Despite being mocked by contemporary commentators (The Times dubbed it 'the Great Bore', because of the length of time it took - Cruickshank 1995) the enterprise proved that the shield principle made subaqueous soft soil underground tunnelling possible (see Figure 5).

When it finally opened, in 1843, the Thames Tunnel, its spacious and elegantly finished twin tunnels running sideby-side, was a huge success, at least as far as tourists and visitors were concerned. An American traveller, William Allen Drew (Glimpses and Gatherings, 1852), called it

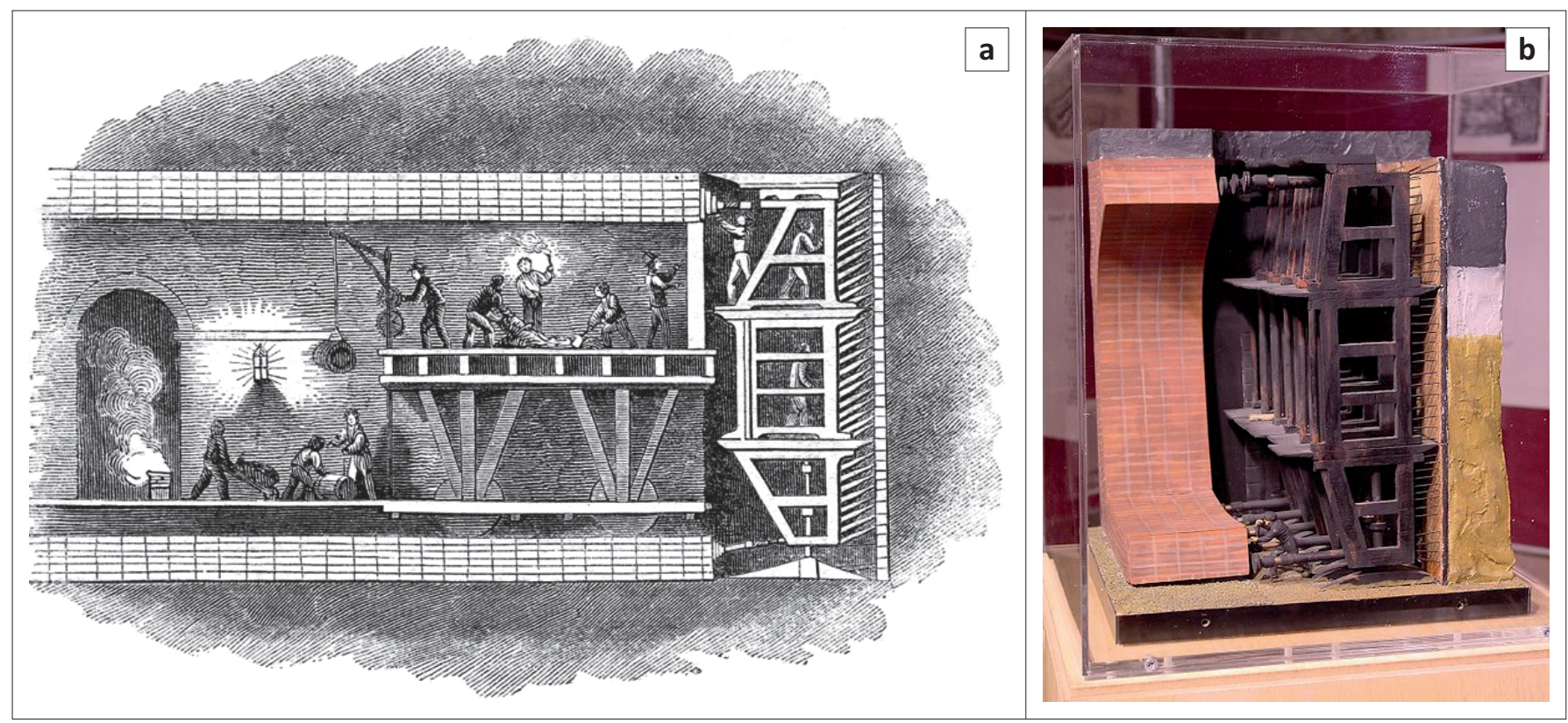

Source: (a) Wikipedia, n.d.f, 'Diagram of the tunnelling shield used to construct the Thames Tunnel, London', viewed 14 July 2016, from https://commons.wikimedia.org/w/index.php?curid=661928; (b) Wikipedia, n.d.g, 'A scale model of Marc Brunel's tunnelling shield in the Brunel Museum at Rotherhithe (Photo: Duncan Kimball)', viewed 14 July 2016, from https://commons.wikimedia.org/w/ index.php?curid $=8375450$

FIGURE 4: How Brunel's tunnelling shield worked: (a) Contemporary magazine illustration and (b) scale model at the Brunel Museum. 


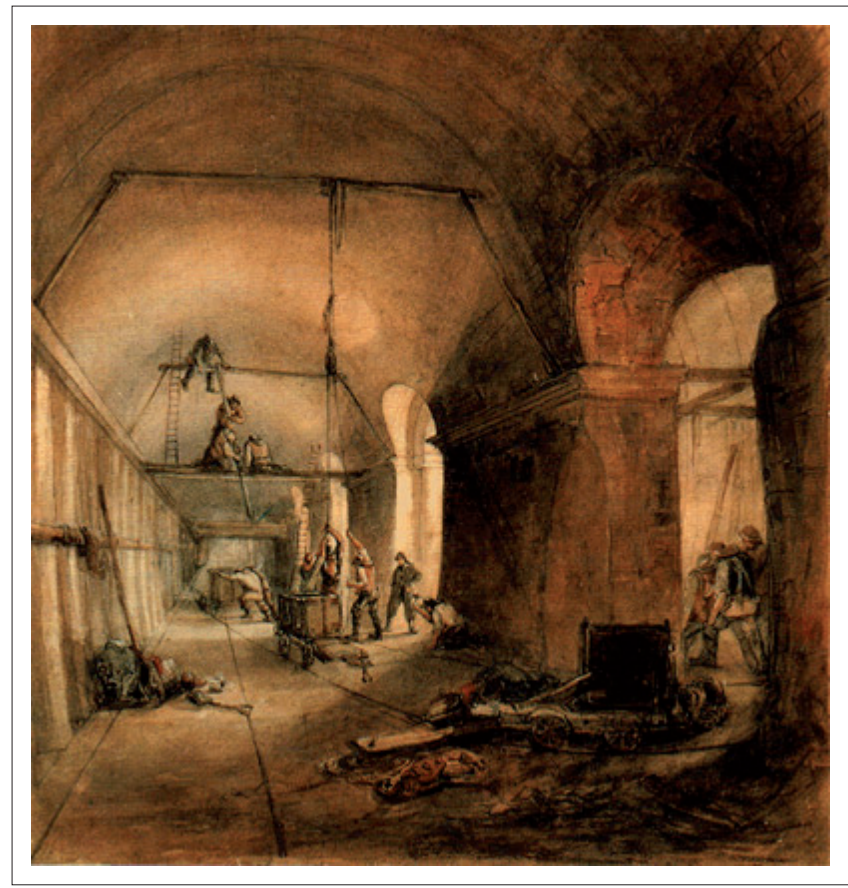

Source: Wikipedia, n.d.h, 'Inside the Thames Tunnel During Construction, 1830', viewed 14 July 2016, from https://commons.wikimedia.org/wiki/File:Thames tunnel construction 1830.jpg

FIGURE 5: Brunel's Thames Tunnel under construction: The archways between the two tunnels became retail spaces.

'the eighth wonder of the world' and, while professing himself 'somewhat disappointed in it', probably because it was not yet conveying bulk goods as originally intended, he left an enthralling description of what had turned unexpectedly into the world's first underwater shopping mall:

We enter by one of several great doors, and find ourselves in a rotunda of fifty feet diameter, and the floor laid in mosaic work of blue and white marble. The walls are stuccoed, around which are stands for the sale of papers, pamphlets, books, confectioners, beer, \&c. A sort of watch-house stands on the side of the rotunda next the river, in which is a fat publican, or tax gatherer. Before him is a brass turnstile, through which you are permitted to pass, on paying him a penny, and, entering a door, you begin to descend the shaft, by a flight of very long marble steps that descend to a wide platform, from which the next series of steps descends in an opposite direction. The walls of the shaft are circular, finished in stucco, and hung with paintings and other curious objects. You halt a few moments on the first platform and listen to the notes of a huge organ that occupies a part of it, discoursing excellent music.

You resume your downward journey till you reach the next story, or marble platform, where you find other objects of curiosity to engage your attention whilst you stop to rest. And thus you go down - down - to the bottom of the shaft eighty feet; the walls meanwhile, being studded with pictures, statues, or figures in plaster, \&c. Arrived at the bottom, you find yourself in a rotunda corresponding to that you entered from the street, a round room, with marble floor, fifty feet in diameter. There are alcoves near the walls in which are all sorts of contrivances to get your money, from Egyptian necromancers and fortune-tellers to dancing monkeys. The room is lighted with gas, and is brilliant. Now look into the Thames Tunnel before you. It consists of two beautiful Arches, extending to the opposite side of the river.
These Arches contain each a roadsted, fourteen feet wide and twenty-two feet high, and pathways for pedestrians, three feet wide. The Tunnel appears to be well ventilated, as the air seemed neither damp nor close. The partition between these Arches, running the whole length of the Tunnel, is cut into transverse arches, leading through from one roadsted to the other. There may be fifty of them in all, and these are finished into fancy and toy shops in the richest manner - with polished marble counters, tapestry linings gilded shelves, and mirrors that make everything appear double. Ladies, in fashionable dresses and with smiling faces, wait within and allow no gentleman to pass without giving him an opportunity to purchase some pretty thing to carry home as a remembrancer of the Thames Tunnel. The Arches are lighted with gas burners, that make it as bright as the sun; and the avenues are always crowded with a moving throng of men, women and children, examining the structure of the Tunnel, or inspecting the fancy wares, toys, \&c., displayed by the arch-looking girls of these arches ... It is impossible to pass through without purchasing some curiosity. Most of the articles are labelled - 'Bought in the Thames Tunnel' - 'a present from the Thames Tunnel'. (pp. 245-247)

On the first 2 days, 50000 people descended the staircases and paid a penny to walk through the tunnel. By the end of the first 3 months a million people, or half the population of London, had visited the tunnel, the crowds at times outstripping those attending the Great Exhibition in Hyde Park. For several years, more than 2 million people visited annually. The tunnel became the most successful single tourist attraction in the world, a celebration of mid-Victorian achievement, frivolity and grandiosity, signalling the beginnings of the period Burn (1964) would later dub the Victorian 'age of equipoise' (see Figure 6).

However, in terms of its original purpose, as the American novelist Nathaniel Hawthorne pointed out, the project was 'an entire failure' (1855, The English notebooks, 21:351). Drew called it 'more of a curiosity-shop than a passage-way' (1852:245). The fundamental problem was that, after all his struggles with the project, Brunel could not raise the additional finance to build the ramp-ways at either end which would allow access to wheeled traffic. The result was, in today's commercial parlance, a massive failure of business alignment (see Lydon 2012). The tunnel's primary purpose of relieving the press of bridge traffic by providing swift and cheap passage for goods under the river could never be realised.

Towards the end of the 1840s, as its novelty declined, muggers and prostitutes earned the tunnel an unsavoury reputation, and the crowds departed. In 1865 it was bought by the East London Railway Company, proceeds from the sale being used to repay a long-standing government loan. Longsuffering investors, who had contributed some $£ 180000$ to the project, lost all their money (Beaver 1973:45), but at least the tunnel had found a use. Years later, its glamorous décor ignored, the tunnel became part of the London Underground the oldest infrastructural component of the system - until in 2010 it was once more incorporated into British Rail's overground system as an ordinary railway tunnel. Brunel's Engine House in Rotherhithe is now home to the Brunel 


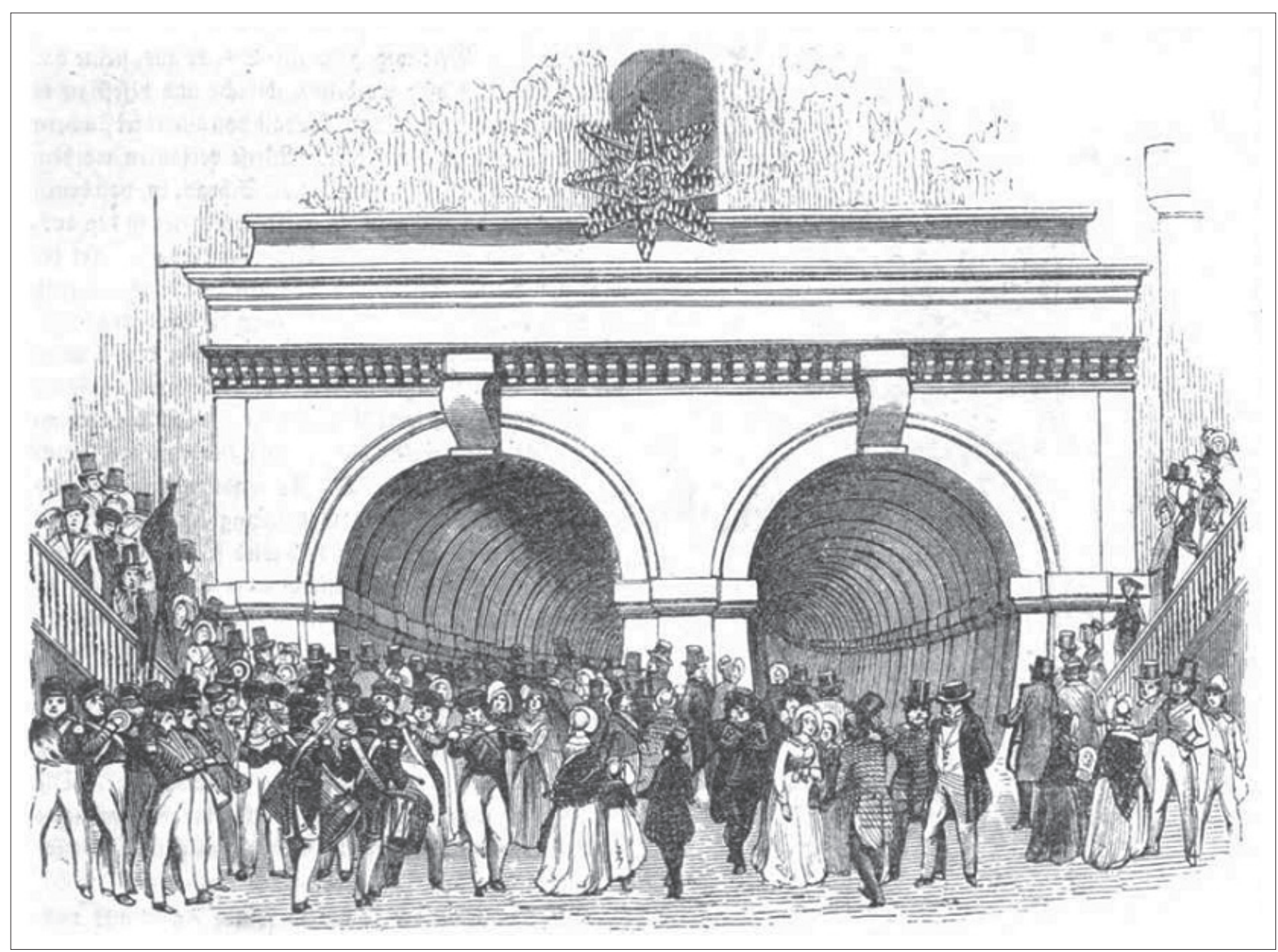

Source: Wikipedia, n.d.i, 'Tunneleang on the river side of Rotherhithe', viewed 14 July 2016, from https://de.wikipedia.org/wiki/Datei:Illustrirte_Zeitung_(1843)_01_006_2_Tunneleingang_an_ der_Flu\%C3\%9Fseite_von_Rotherhithe.PNG

FIGURE 6: The Tunnel's Rotherhithe Entrance: Entertainment and retail therapy supplant the original economic purpose.

Museum, while the grand Wapping Entrance House described by Drew has been revamped as a trendy performance venue (Harris 2016). A section of the tunnel itself is today a Grade II listed building (see Figure $7 \mathrm{a}$ and $7 \mathrm{~b}$ ).

\section{The Tower Subway}

The experience had been punishing from start to finish and, unsurprisingly, it was not until 1868 that a second subaqueous Thames tunnel project was bruited. The instigator was Peter W. Barlow, Greathead's old engineering mentor. He put forward the idea of a subway under the Thames, running from Tower Hill on the north bank, near the Tower of London, to what was then Vine Street on the south bank, a site now occupied by London's City Hall, at a depth varying between 22 feet and 32 feet below the river bed. This greater depth, siting the project deep in London Clay rather than replicating the treacherous shallow drive, in loose water-bearing material, tackled by Brunel, was no small influence on the project's engineering success (Pedroche 2013; West 2005).

The Tower Subway venture was a try-out for Barlow's thinking on how to solve London's crippling traffic problems. On top of huge population growth, the issue was that long- distance railways from different parts of the country, operated by different companies, had converged on London from all directions, their termini forming a ring around the city's central district. Travellers could get to London, but could not get about in London. The inner city was too congested.

Railway entrepreneurs were barred from building lines across London because of the drastic disruption caused to road traffic for long periods during construction. Inventive proposals to solve the transport problem had been advanced over a period of 50 years, including suggestions for underground railways, pneumatic railways and 'Railways high in the air, over the tops of the buildings' (Greathead 1896:5). In 1867, Peter W. Barlow put forward a fanciful scheme of 'omnibus subways' for London. Passengers would travel in underground buses, 12 persons to a bus, the buses running inside steel tubes, 8 feet $(2.4 \mathrm{~m})$ in diameter, to be built using a shield technology. The tubes were to be structured on three different levels, with the buses propelled by a combination of gravity and manpower. Passengers would pay on the buses, which could stop and be boarded on one level only. Lifts situated at this payment level would raise the buses to higher levels, where gravity could 

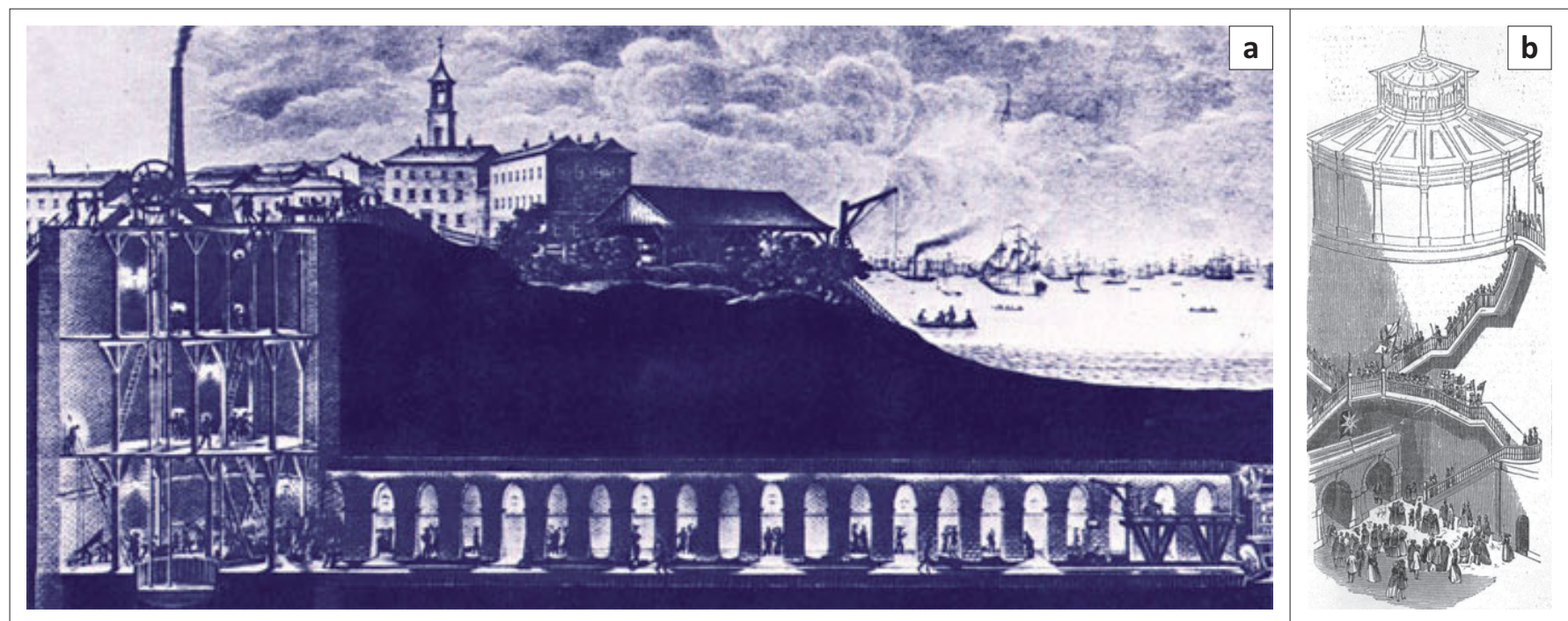

Source: (a) Wikipedia, n.d.j, ‘Thames Tunnel 1840', viewed 14 July 2016, from https://commons.wikimedia.org/wiki/File:Thamestunnel1840.jpg; (b) Wikipedia, n.d.k, 'Thames Tunnel shaft', viewed 14 July 2016, from https://en.wikipedia.org/wiki/File:Thamestunnelshaft.gif

FIGURE 7: Brunel's Caisson: A world first: (a) Lithograph by Taulman after Bonisch and (b) the grand North-West Entrance Hall which today is a trendy performance space.

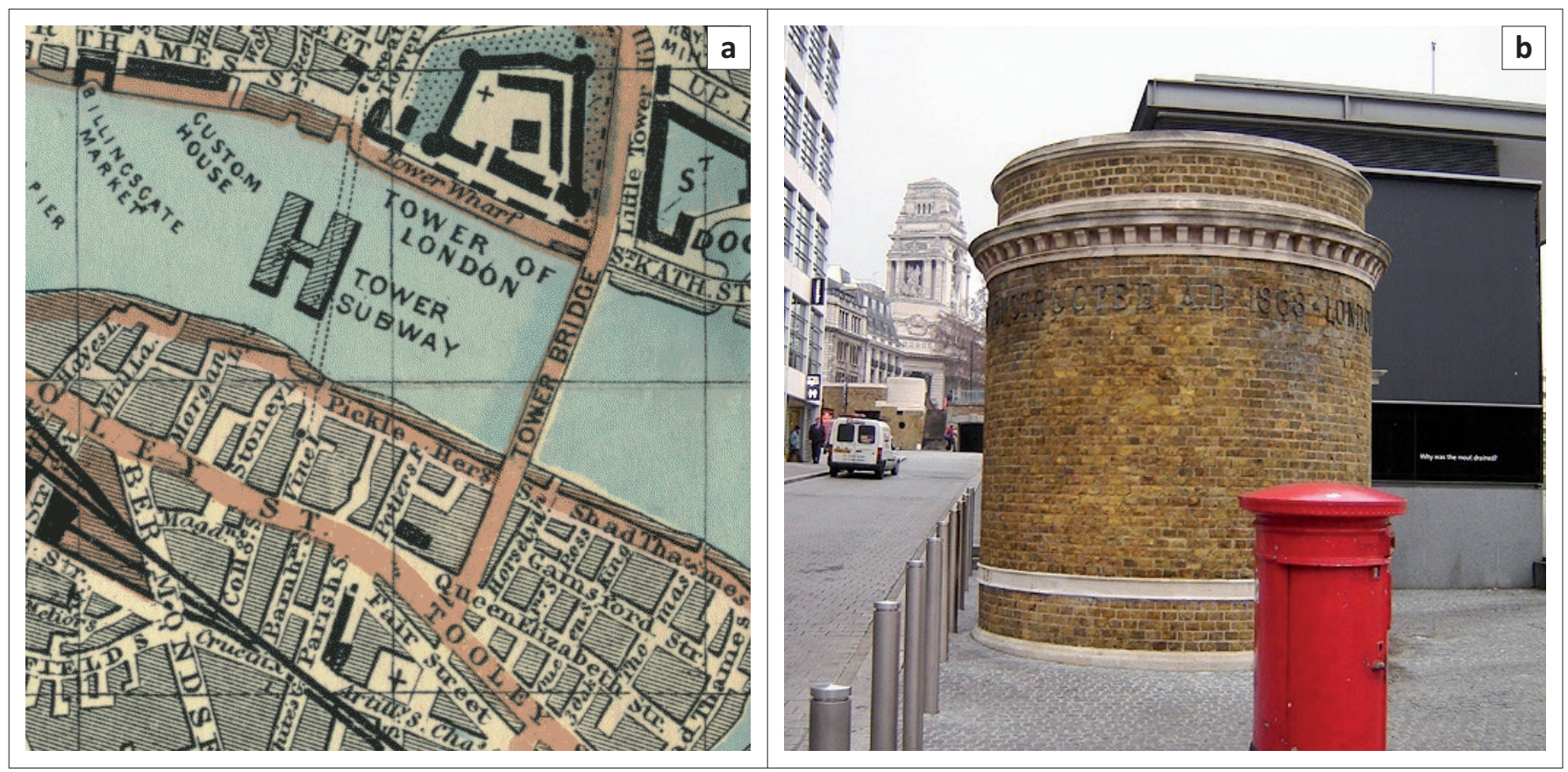

Source: (a) Wikipedia, n.d.I, 'Location of the en:Tower Subway, London. Extracted from Reynolds' Shilling Map, en:1895', viewed 14 July 2016, from https://commons.wikimedia.org/wiki/ File:Tower_subway_map.gif; (b) Wikipedia, n.d.m, 'Tower Subway, northern entrance kiosk', viewed 14 July 2016, from https://en.wikipedia.org/wiki/File:Tower_subway_1.jpg

FIGURE 8: The Tower Subway (a) Location of the Tower Subway and (b) Northern Entry as it is today. Lettering reads: 'CONSTRUCTED A.D. 1868 - LONDON'.

take over. Disregarding the eccentric motive power, Barlow had adumbrated the idea of the deep London Underground. His Tower Subway, in addition to its overt purpose of competing with the river ferries, was a first experimental step towards this grand scheme (see Figure $8 \mathrm{a}$ and $8 \mathrm{~b}$ ).

Following the Thames Tunnel's disastrous decline in popularity, there had been no further subaqueous tunnelling initiatives for London, but fresh engineering ideas had flourished nationally and internationally. Samuel Dunn, of Doncaster, took out a patent (No. 12634 of 1849) for a cylindrical tunnelling machine, its nose shaped rather like a ploughshare. The shield worked within a cylindrical metal 'skin', like a hydraulic or atmospheric ram, pushing off the tunnel construction behind it and forcing forward a huge piston-head the diameter of the tunnel. The sheer size of the head was clearly problematic and the patent, more a sketch than a fully worked out design, was never attempted (Copperthwaite 1906:7). In 1857, the French mining engineer, Theophile Guibal (1814-1888), devised a machine for tunnelling vertically in shifting sands, an early adaptation of Brunel's shield method, while the early 1860s saw the Austrian engineer, Frans von Ržiha (1831-1897), pioneer a system in which concentric moveable centres, made of iron, were successively removed at the tunnel face, again a notion clearly derived from Brunel's concept. Ržiha's method was used successfully for constructing railway tunnels (Copperthwaite 1906:8), but the rival shield technology was 
gaining unstoppable momentum. Much of the innovation came, again, from the fertile intellect of Peter W. Barlow.

In 1864, with railway tunnels in mind, Barlow patented a design (No. 2207 of 1864) for a cylindrical steel or iron shield which would progress as a unit, unlike the staggered progress of Brunel's rectangular model. ${ }^{11}$ The thin cylindrical forward edge would cut into the soil or clay, as would a rank of sharp, parallel, vertical plates running across the face of the shield. ${ }^{12}$ The space between the tunnel skin and the surrounding earth should be filled with cement grout. This latter suggestion of Barlow's led to the invention of Greathead's patented grouting apparatus (No 5221 of 1886). ${ }^{13}$ Then, in 1886, Barlow patented another potential improvement: a transverse opening partition or diaphragm in the shield which could seal off the upper portion, creating an air-locked chamber to protect workers in the event of flood incursion. With these two patents of 1864 and 1886 by Peter W. Barlow, the suite of concepts eventually embodied in the device known as the Greathead Shield was complete.

Implementation was another matter. When the Tower Subway went to tender in 1868, not one engineering contractor responded (Brunel's troubles with the Thames Tunnel, experienced over a period of 26 years, had left the entire profession daunted). That is, until young James Henry Greathead, aged 24, tendered for the contract, saying he would build the tunnel in under a year at a cost of under $£ 10$ 000. He achieved both goals.

The commissioning engineer was Peter W. Barlow - as we have seen, the subway was his idea - with Greathead as the contracting engineer in charge. Greathead designed the shield based on Barlow's ideas, supervised its construction and personally oversaw the tunnel drive. Like Brunel's shield, Greathead's was designed to be jacked forward using the purchase of the tunnel lining constructed behind it. The shield excavated a cut slightly larger than the casing of the tunnel, at 7 feet 3 inches $(2.2 \mathrm{~m})$, and the lining was composed of iron ring-liners, each 18 inches $(0.5 \mathrm{~m})$ in length, and some 7 feet $(2 \mathrm{~m})$ in diameter. These rings were bolted into place, one after the other behind the shield, as it moved forward, and liquid cement was forced through special holes in the tunnel lining to bond with the clay of the river bed, thus shielding the ironwork from the mud surrounding it and preventing oxidisation. Six of these rings could be bolted and

11.Copperthwaite (1906:7) notes that Law (1845-1846) maintained that the rectangular form of Brunel's shield was adopted 'on account of the better resistance it offered to constantly varying pressures due to the rise and fall of the tides'. Greathead's view (1896:55) was that the rectangular profile was chosen by Brunel simply as being more 'suitable' for his form of shield.

12.Barlow's idea was inspired by working for his father (also called Peter Barlow) on the Lambeth suspension bridge across the Thames (now demolished). The piers for the bridge were cast-iron cylinders driven vertically into the riverbed. Barlow flipped the idea on its side. His concept was to drive a steel or wrought-iron cylinder horizontally along the tunnel trajectory, with cutting plates or 'teeth' mounted at the farther end.

13.Effective grouting to support the interface between the tunnel and surrounding strata played no small part in the efficacy of shield tunnelling. The Tower Subway compres accomplished using a hand held sy compressed-air grouting pan, invented in 1886 (West 2005:158-160), became ubiquitous in shield tunnelling. The technology was later adapted by Sir Francis Fox in restoring stone grouting at Winchester Cathedral (1905), St. Paul's Cathedra (1906 and 1926) and Lincoln Cathedral (1922-1927) (Mitronatsios et al. 2010). sealed in place in a day, meaning that the tunnel progressed at the remarkable pace of 9 feet a day.

This is why London's Underground earned its nickname of 'The Tube': the Tower Subway was essentially an extruded steel tube running under the river. A stationary $4 \mathrm{hp}$ steam engine was installed to pump the shafts at either end clear of water, and another to power a 2 foot 6 -inch $(0.76 \mathrm{~m})$ gauge railway to draw a single passenger-laden tram back and forth under the Thames using a cable haulage system. Each tram (dubbed an 'omnibus' by the operators) carried some 12 persons, the journey took about 3 minutes, and it cost a penny for second class and tuppence for first (see Figure 9).

Again, sadly, the project was a commercial failure because engineering innovation was not properly aligned with economic viability. Pedestrians could cross the Thames by bridge easily, free of charge. Why pay? So the pioneering underground rail service which opened on 12 April 1870 was closed on 7th December the same year. Such was the fate of the world's first under-river railway.

When the rail service ended, the tunnel had some success as a pedestrian subway (price one halfpenny), but once a raised wooden walkway replaced its rails, the 7-foot diameter meant that headroom became a problem except in the very centre of the tunnel. In his Dictionary of London (1879) Dickens's son, Charles Dickens Jnr, noted that:

it is not advisable for any but the very briefest of Her Majesty's lieges to attempt the passage in high-heeled boots, or with a hat to which he attaches any particular value. (p. 252)

The opening of the nearby Tower Bridge in 1896 finally put paid to the enterprise. The Tower Subway closed to the public in 1898 and was sold to the London Hydraulic Power Company (LHPC), which used it to carry hydraulic mains. The LHPC at one time had some 180 miles $(290 \mathrm{~km})$ of highpressure piping conveying hydraulic power to a variety of customers between Hyde Park and the docklands of East

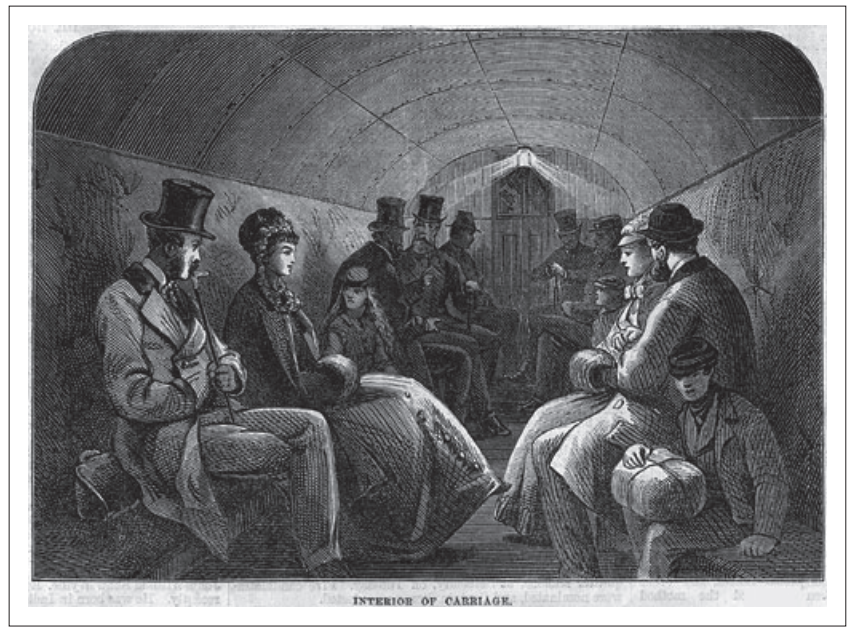

Source: Wikipedia, n.d.n, 'Tower subway carriage', viewed 14 July 2016, from https:// commons. wikimedia.org/w/index. php?curid=299712

FIGURE 9: Contemporary illustration: Interior of the Tower Subway 'Omnibus', 1870. 
London, including the revolving theatre stages at the Palladium and the London Coliseum. The tunnel remained watertight, even surviving a near miss in 1940 during the 'Blitz' without yielding. The LHPC finally closed in 1977, and today the tunnel carries ordinary water mains and telecommunication cables.

What was it like to experience the Tower Subway? A vivid evocation survives in a travelogue, Ricordi de Londra (1873, transl. S. Parkin, 1970), by the Italian poet and novelist Edmondo de Amicis (1846-1908), reproduced here in translation:

\begin{abstract}
... I disappeared from the world indeed, going down a lighted spiral staircase which buries itself in the earth on the right bank of the Thames, opposite the Tower. I went down and down between two dingy walls until I found myself at the round opening of the gigantic iron tube, which seems to undulate like a great intestine in the enormous belly of the river. The inside of this tube presents the appearance of a subterranean corridor, of which the end is invisible. It is lighted by a row of lights as far as you can see, which shed a veiled light, like sepulchral lamps; the atmosphere is foggy; you go along considerable stretches without meeting a soul; the walls sweat like those of an aqueduct; the floor moves under your feet like the deck of a vessel; the steps and voices of the people coming the other way give forth a cavernous sound, and are heard before you see the people, and they at a distance seem like great shadows; there is, in short, a sort of something mysterious, which without alarming causes in your heart a vague sense of disquiet. When then you have reached the middle and no longer see the end in either direction, and feel the silence of a catacomb, and know not how much farther you must go, and reflect that in the water beneath, in the obscure depths of the river, is where suicides meet death, and that over your head vessels are passing, and that if a crack should open in the wall you would not even have the time to recommend your soul to God, in that moment how lovely seems the sun!
\end{abstract}

I believe I had come a good part of a mile when I reached the opposite opening on the left bank of the Thames; I went up a staircase, the mate of the other, and came out in front of the Tower of London. (De Amicis 1873)

Though these first two tunnels under the Thames were economic failures, they were also substantial engineering achievements, with this dramatic difference: where Brunel's Thames tunnel project ran for some 19 years, including all the disasters and interruptions, excavation of Greathead's Tower Subway took 14 weeks for 900 feet of horizontal tunnel, plus two vertical 60 -foot shafts at either end, the entire system being approximately 1230 feet long. As a bold engineering experiment, Greathead's expeditious construction of the Tower Subway was indeed a triumph, and a foretaste of things to come.

\section{Solving London's transport problems: The City and South London Railway}

The Tower Subway experience provided the template for the construction in 1890 of The City and South London Railway, prototype of London's deep level Underground system. The initiative was spearheaded by Greathead, who lobbied Parliament on behalf of the project. As chief engineer, he designed the shields used, which were much larger than those used for the Tower Subway, and oversaw the tunnel drives. His expertise was critical to turning the idea of underground public transport, deep beneath the tangled congestion of central London, an area densely built-up both above and below ground level, into a viable project - the beginnings of mass, deep level underground transportation.

The city's first two underground lines, the Metropolitan railway and the district railway, had been built in the 1860s with great success, but the cut-and-cover methods employed caused such protracted traffic disruption that no such further projects were allowed (see Figure 10).

The only solution was to go deeper. There had been a 15-year lull in subaqueous tunnel construction after the Tower Subway, during which Greathead designed an innovative shield for a proposed tunnel under the Thames at Woolwich, incorporating a water seal and employing compressed air to force water back from the working face to keep it dry (Patent 173 of 1874). The concept was not new. As far back as 1830, Sir Thomas Cochrane had patented a system for using compressed air in subaqueous tunnelling, incorporating an air-lock, but it had never been practically applied (West 2005:131). The idea was that if air pressure inside the drive could be maintained to equal that of water trying to enter the shield, water ingress would be halted. Exceeding the pressure of the incoming water risked blowing a hole in the riverbed, possibly flooding the tunnel. Regrettably, the Woolwich project collapsed before Greathead could test his shield design. Instead he had to follow, at a distance but with great interest, two projects in the United States. Alfred Ely Beach, co-founder (in 1845) of the magazine Scientific American, bored a pneumatic subway under Broadway in New York using his own shield based on Barlow's designs. The venture was financially unsuccessful and did not last. More interesting, because counter to Greathead's own thinking, was the progress of a tunnel under the Hudson River between New York and Jersey, engineered by De Witt Haskin who, without the benefit of shield technology, used compressed air in the manner of Cochrane's patent to prevent water seeping into his tunnel through the soft mud of the river bed. In addition, Haskin drew on the example of James Eads who, also impressed by the 1830 Cochrane patent, had used compressed air in the construction of the caissons for his bridge over the Mississippi (Beaver 1973:85). Despite a tragic collapse in July 1879 , in which 20 workers were drowned, Haskin's Hudson River project confirmed Greathead in his belief that incorporating Cochrane's compressed air technology would be crucial to any future success of the shield technology. His opportunity came with London's first deep level underground 'tube' railway, 'The City of London and Southwark Railway', later renamed The City and South London Railway.

Greathead put forward a private bill in Parliament in November 1883 for the construction of the railway. It was to run north from Stockwell under the Thames in two tunnels, 10 


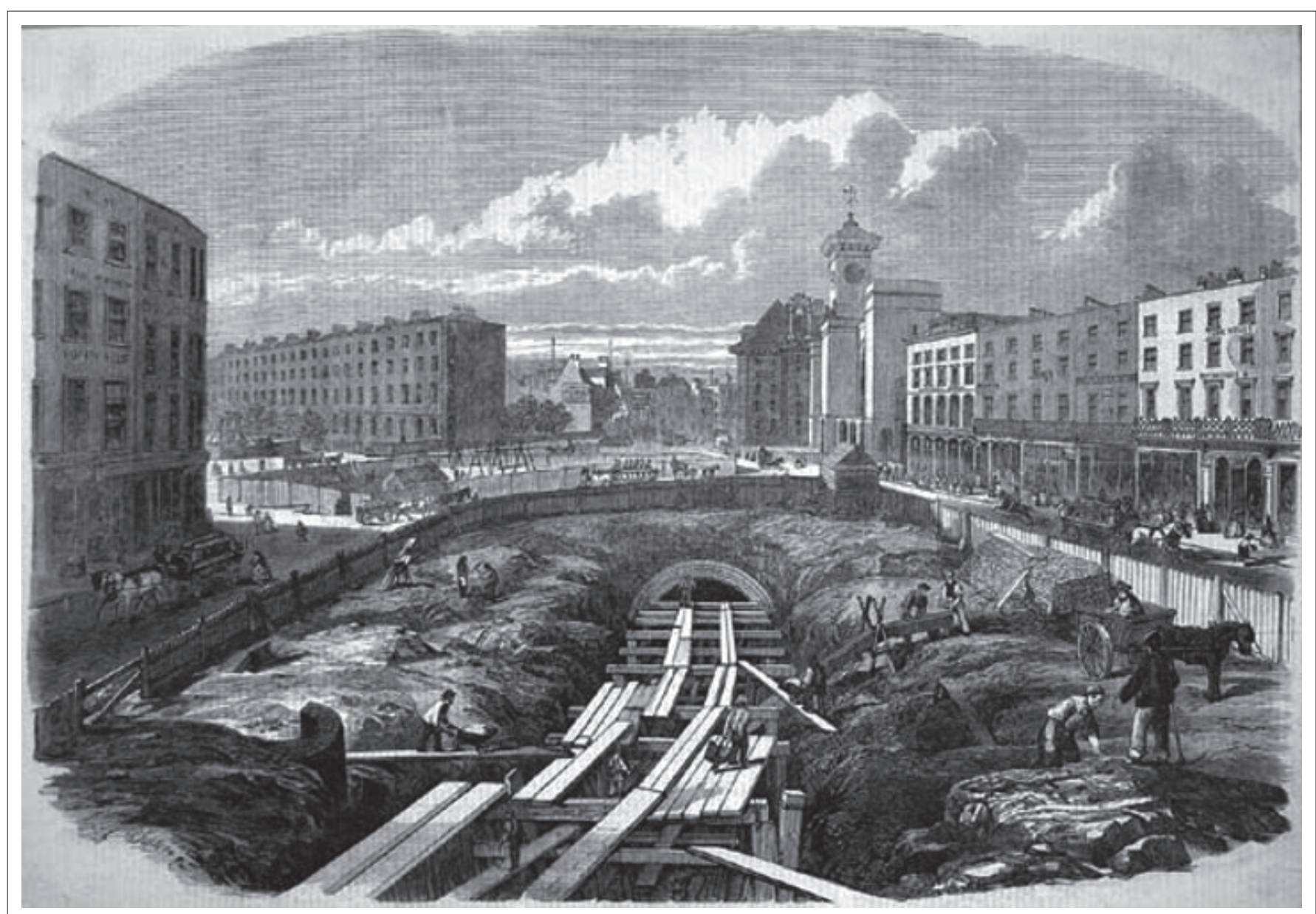

Source: Wikipedia, n.d.o, 'Constructing the Metropolitan Railway', viewed 14 July 2016, from https://en.wikipedia.org/wiki/File:Constructing_the_Metropolitan_Railway.png

FIGURE 10: Cut-and-cover construction on the Metropolitan Line, the world's first underground railway, which opened 10 January 1863 . Wooden, gas-lit carriages, hauled by steam, carried passengers between Bishop's Road, Paddington, and Farringdon.

feet 2 inches $(3.1 \mathrm{~m})$ in diameter, terminating at King William Street in the City of London, with himself as chief engineer. In 1886, he submitted another bill permitting the tunnels to be extended further south to Kennington from Stockwell, with slightly larger diameter tunnels (10 feet 6 inches; $3.2 \mathrm{~m}$ ). Access to the tunnels would be by stairwells and hydraulic lifts. The railway ran for 2.6 miles $(4.2 \mathrm{~km})$, in a pair of tunnels passing under the Thames between Stockwell in the south to the City of London (see Figure 11). The City and South London Railway (C\&SL) was originally designed for cable haulage, like the Tower Subway, but the unexpected dissolution of the cable contractor (The Patent Cable Tramway Corporation Limited) precipitated a change to electricity. Its generating power station was built at Stockwell, and the system employed third-rail electrification. So that the C\&SL became, in addition, the first major railway in the world to use electric traction.

Critical to the success of the C\&SL tunnel drives was the incorporation of compressed air technology for short stretches of the drive, enabling excavation to proceed even where the tunnels broke free of London Clay into sand and gravel. In phases of compressed air working under the river, air could be seen bubbling up through the river bed from the tunnel beneath, while the workers experienced no incursions (West 2005:140). The railway was sited mainly in London Clay but, especially towards the south end of the line, beneath the Clapham road near Stockwell, the tunnels were driven through coarse water-bearing gravel and sand. The experience proved that the combination of shield and compressed air was crucial for subaqueous tunnelling in such conditions.

The new railway was opened by the Prince of Wales on November 4th, 1890. In its first 6 months, 174000 train miles were run, carrying 2412000 passengers; by the end of the year the figure was 5.5 million passengers; and in 1894, 6900000 passengers and 485000 train miles. Engineering and economics were aligned. The City and South London Railway was a success, and the beginnings of a practical solution to London's transport problems - the deep level Underground - had been found. The transport solution has been replicated across the world (see Figure 12).

\section{Conclusion}

This account of Greathead's role in developing deep level subaqueous tunnelling technology for the London Underground seeks to emphasise the complex historical network of 'extelligence' which eventually led to its successful establishment. Driven by disparate personalities from different lands, the network of extelligence stretches back 
THE WATERLOO A N C T T E LECTRICAL UNDERGROUND RAILWAY

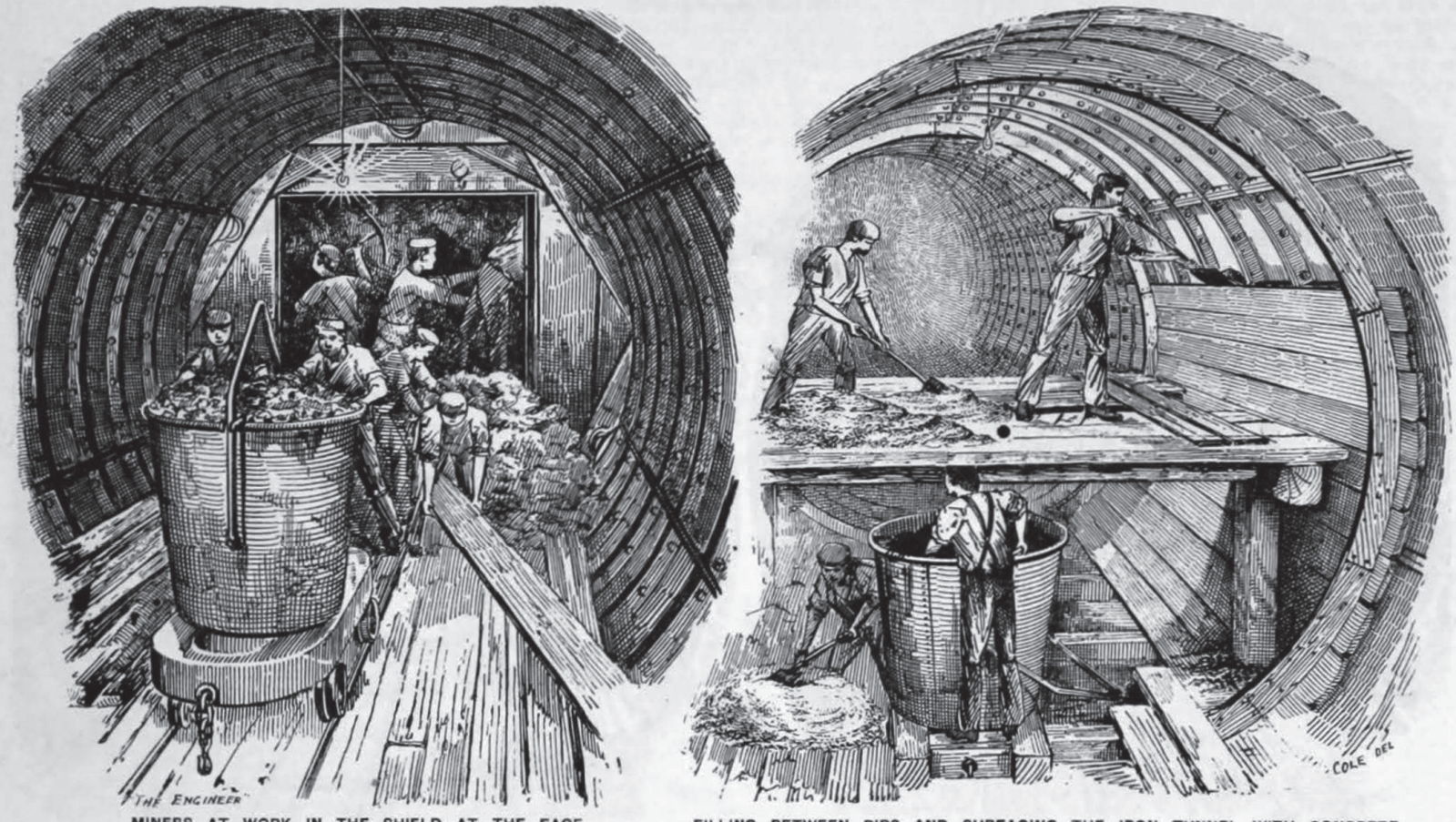

Source: Wikipedia, n.d.p, 'The Greathead tunnelling shield designed by James Henry Greathead in use in the construction of the Waterloo \& City Railway, London', viewed 14 July 2016 , from https:// commons. wikimedia.org $/ \mathrm{w} /$ index. . php?curid $=27820364$

FIGURE 11: The Greathead Shield at work during construction of the Waterloo and City Line.

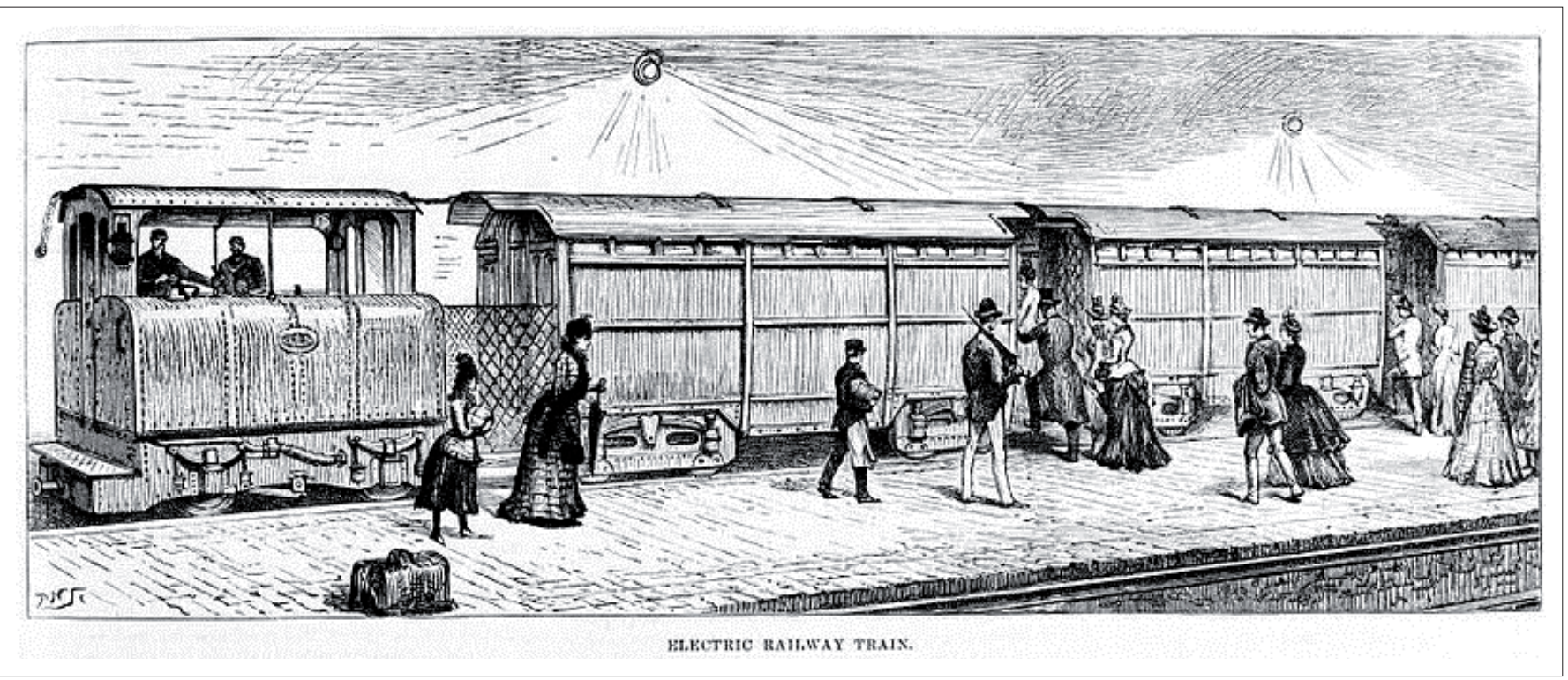

Source: Wikipedia, n.d.q, 'Electric railway train', viewed 14 July 2016, from https://commons.wikimedia.org/w/index.php?curid=300770

FIGURE 12: City and South London Railway: Carriages were nick-named 'padded cells' because of their paucity of windows.

into pre-history, gathers momentum after the Industrial Revolution and culminates in the design and world-wide application of the Greathead Shield. In all, it is a story of synthesis and cooperation across time.

Can it then convincingly be argued that James Henry Greathead 'invented' the Greathead Shield, as the inscription on his statue proclaims? In what sense was he the Father of the Underground, as popular lore has it?

The very notion of a hero is somehow cruelly undemocratic, ignoring the legacy of cooperation across time, all those 'others' whose efforts make the hero's achievement possible, and whose contribution is effaced by concentrating on an 
individual. It is even more anomalous in the field of engineering, where collaboration is essential and taken for granted.

The closer one gets, historically, to the period in which the engineering challenges Greathead overcame were live issues, and not merely the routine problems they became subsequently, the more one realises that LateVictorian criteria for acknowledging outstanding engineering achievement centred almost solely on practical success. Greathead's presentation to his peers at the Institution of Civil Engineers in 1895, the year before his death (Greathead 1896), is scrupulous in acknowledging the patents and ideas of his predecessors, those he knew about and those he did not, and everything he had learned from them. He acknowledges Marc Brunel with great admiration. When he describes the Tower Subway, where the shield was first used with such signal success, he gives Peter W. Barlow, then recently deceased, full credit as designer of the project as a whole. However, when it comes to describing the design, construction and performance of the Shield, he does so in great technical detail - this, after all, was what his audience had mainly come to learn about - thereby making the point that he, as the contracting engineer, and not Barlow, was primarily responsible for turning the shield idea into practical technology. $\mathrm{He}$ is formally putting his own engineering achievement on record in front of his peers, men well qualified to contradict any exaggerated or hubristic assertions. In addition, 10 years later, we have a wonderfully detailed account by one of Greathead's former colleagues, William Copperthwaite (1906), who goes to the heart of the matter when he remarks that:

The exact apportionment of the credit of the invention between these two men will be decided by each reader according as he may consider the original inventor of a new mechanism, or the man who puts it to practical use, the more worthy of credit. (p. 20)

There can be no doubt on which side of the debate Copperthwaite's own estimate settled. He writes (Copperthwaite 1906) that although 'in a sense Mr. Barlow's design must be considered as the type from which the Greathead and Beach shields are modelled', nevertheless

Mr. Barlow's designs ... were never put into practical shape by him, and even the Tower Subway under the Thames, of which he was the original promoter, was built with a shield, of similar character indeed to his 1868 patent, but designed by Mr. Greathead .... Its successful construction was entirely due to $\mathrm{Mr}$. Greathead, who took the contract for the entire scheme from the Company which had obtained powers from Parliament to construct it, devised himself the plant and equipment for the work, and personally superintended its execution. (p. 11)

When, therefore, modern commentators write of the BarlowGreathead shield, they are invoking something that existed only in the realm of ideas. ${ }^{14}$ There was no Barlow-Greathead

14.Even the authoritative Grace's Guide refers to the Barlow-Greathead Shield acknowledging Barlow's intellectual contribution (see http://www.gracesguide co.uk/James Henry Greathead); but in honouring Greathead, public culture has sided with concrete achievements and discernible public benefaction over fertile ideas. Hence the amended Shakespearean epigraph to this essay, from 'Well said, old mole' to 'Well [done], old mole.' The concluding discussion refers.

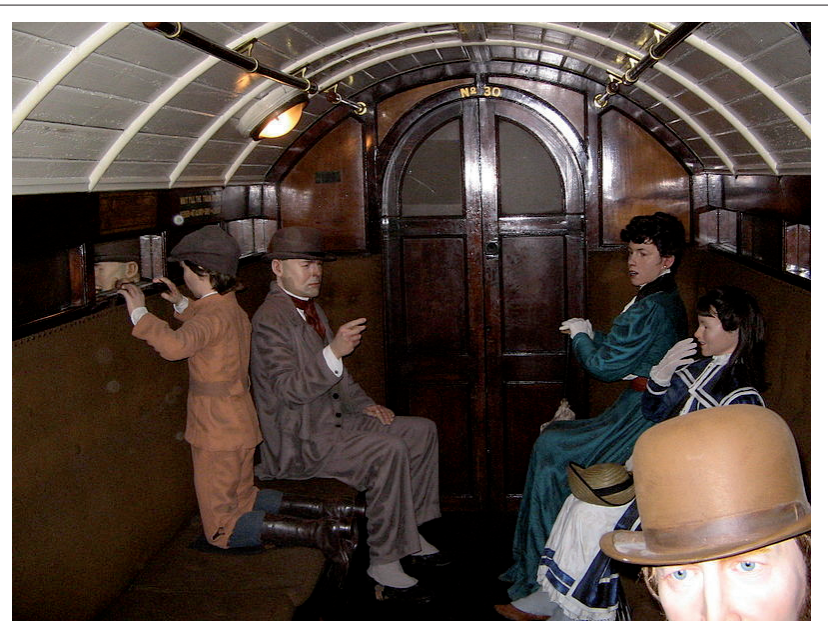

Source: Wikipedia, n.d.r, 'The interior of a C\&SLR padded cell carriage', viewed 14 July 2016 from https://commons.wikimedia.org/wiki/File:C\%26SLR.jpg

FIGURE 13: Transport Museum display: Interior of the 'padded cells' on the C\&SL. It was later realised that passengers on Underground trains preferred proper windows even if there was nothing to see from them!

shield, unless one chooses to rate ideas and plans in the same breath with actual achievement. This the Later Victorians were seldom disposed to do. Barlow was and is acknowledged as a great engineer but, almost a century later and in relation to achieved public good, the fertility of his ideas about public transport, subaqueous tunnelling and shield design were clearly subordinate to Greathead's practical success (see Figure 13).

It could also be argued that Greathead's statue commemorates something much larger than a piece of engineering technology. The memorialisation of engineers in statuary had largely gone out of fashion by the time Greathead's statue was commissioned in the 1990s. Inspired early on by works such as Carlyle's Heroes and Hero Worship (1841), the 'statuemania' of the mid-Victorian period (MacLeod 2007:21), celebrated, among others, the inventors, engineers and projectors of the age in heroic mode, capturing in stone and bronze some of the adulation lavished on them following the Great Exhibition of 1851. But the notion of the engineer as hero faded quickly with the routinisation of engineering and the triumph of theoretical science at the turn of the century. ${ }^{15}$ Where Ruskin (1871) in the 1870s could write his series of letters to the workmen and labourers of Britain under the title Fors Clavigera (force symbolising the club of Hercules; clavis the key of Ulysses symbolising fortitude; and the nail [clavus] of Lycurgus, symbolising fortune), a concatenation of virtues

15.Isambard Kingdom Brunel is an exception, being lavishly memorialised with two statues in London, one on the Embankment near Temple Underground Station, another rather awful one on Paddington Station, and others in Bristol, Milford Haven, Neyland, Plymouth, Saltash and Swindon. In 2010, Brunel was voted the second greatest Briton after Churchill. George Stephenson's statue (1862) stands outside Newcastle Central Station; his son, Robert's (1871), in the forecourt of Euston Station, but the nearest engineering equivalent to the Greathead statue would be that erected in 1901 on the Victoria Embankment honouring Sir Joseph Bazalgette, the civil engineer who redesigned London's sewer network, including the Thames embankments, a scheme which had the unintended consequence of the Thames embankments, a scheme which had the unintended consequence of eliminating cholera in the water, and reducing the incidence of typhus and typhoid. Interestingly, the impulse to memorialise engineers may be reviving: in addition to Greathead's statue, witness the Thomas Telford statue sculpted in 1987 by Andre Wallace and erected in the town named after him, Telford in Shropshire; and the statue of the locomotive designer, Sir Nigel Gresley (unfortunately minus his
favourite Mallard duck, for which his most famous locomotive was named), unveiled at King's Cross in 2016. 


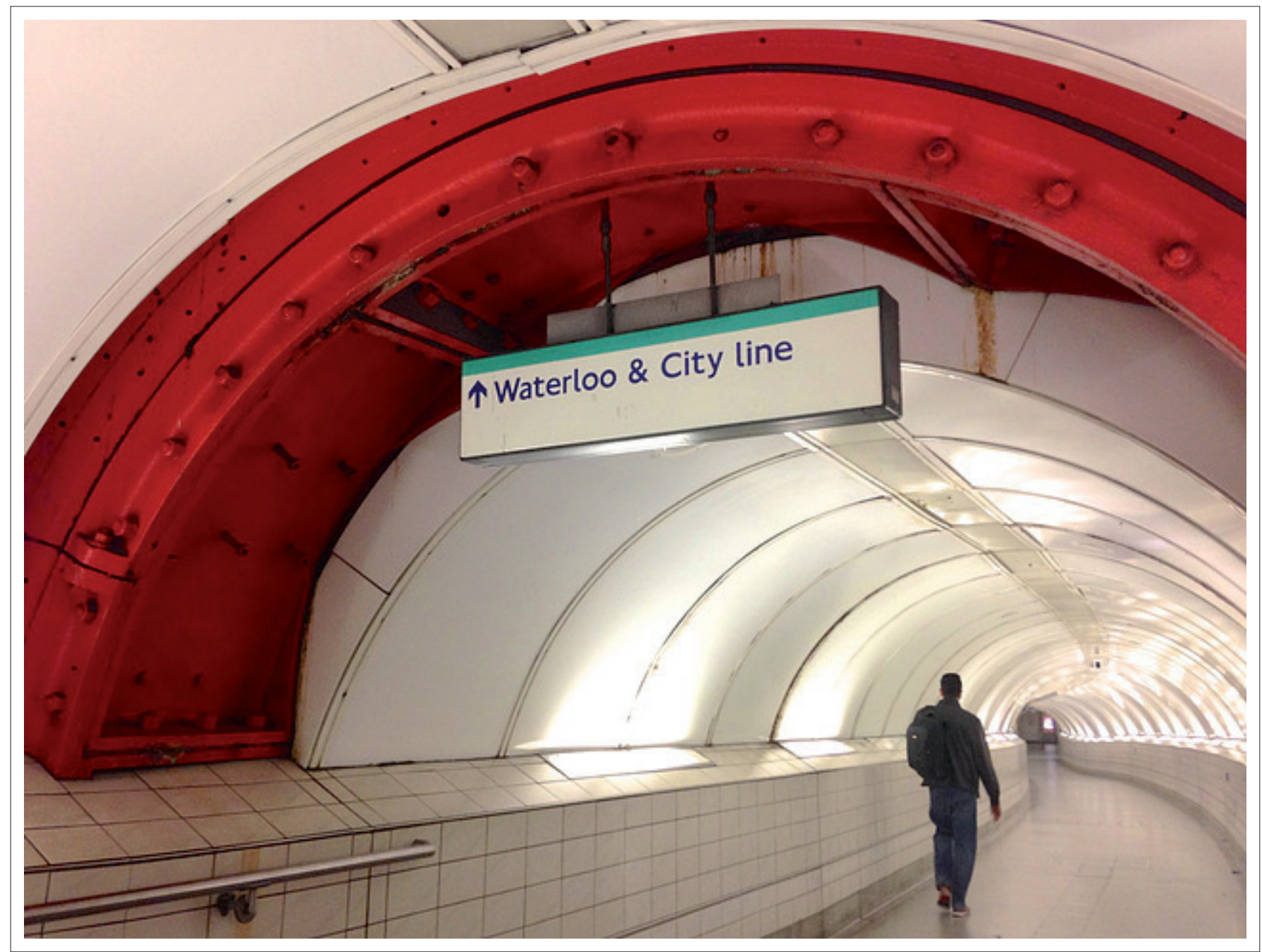

Source: Vail, A., 2014, 'Greathead Tunnelling Shield at Bank Station', viewed14 July 2016 http://www.ipernity.com/doc/avail/31366645

FIGURE 14: Bank Station: Remains of a discarded Greathead Shield used in building the Waterloo and City Line.

Greathead possessed in large measure, the beckoning century introduced the new age of James Clerk Maxwell, Einstein, Niels Bohr and Max Planck, figures whose modes of intellection placed them notionally outside and beyond the belated tropes of Greece and Rome.

Christine MacLeod calls Greathead 'a previously unsung hero of Victorian engineering' (2007:388). And, as Lucy Hughes-Hallet (2005) has pointed out, one of the key features of a hero (or heroine) is that he or she is essentially inimitable. The hero's achievement can never be replicated. There can never again be one man who pulls together the engineering extelligence of centuries of experience and experimentation to create a practical solution for the world's urban transport problems. In this sense, James Henry Greathead is the father of the London Underground, and indeed, of underground public transport across the world.

But neither can we rule out elements of the purely adventitious in so honouring Greathead. Symbolism accrues in mysterious ways. It happened that in 1987 the abandoned remains of a Greathead Shield, discarded after the construction of the Waterloo and City Line, were uncovered at Bank Station during the construction of the Docklands Light Railway (DLR). Greathead had been a joint engineer for the Waterloo and City Line, the shortest line on the Underground system, linking the southern terminus of Waterloo to the City of London, and he died during its construction, in 1896, some 2 years before the line opened. In 1937, the city terminus of the Waterloo line was renamed Bank Station and, every day, thousands of passengers pass heedlessly through the remnants of that discarded Greathead Shield (painted red and marked by a discreet brass plaque) in a pedestrian tunnel linking the DLR to the Waterloo and City Line at Bank Station, above which, of course, there now stands the statue of James Henry Greathead, commanding his island plinth in the middle of Cornmarket (see Figure 14). A special place, a technological relic, and a public memorial coalesce. They are linked as much by the engineering 'extelligence' of hundreds of years of experimentation in soft ground tunnelling, in many lands, as by the practical need to build a ventilation shaft there for London's Underground.

Nevertheless, were it not for the careless dropping of a lighted match at Kings Cross Station in 1987, producing the horrendous fire which led to the requirement to build that 
vent above Bank Station, would the young man from Grahamstown have been honoured in this fashion? So many adventitious threads come together in the creation of a hero.

\section{Acknowledgements Competing interests}

The author declares that he has no financial or personal relationships which may have inappropriately influenced him in writing this article.

\section{References}

Agricola, G., 1556, De re metallica, Froben, Basel.

Agricola, G., 1950 [1912], De re metallica, transl. H.C. Hoover and L.H. Hoover, Dover Publications, New York.

Beaver, P., 1973, A history of tunnels, Citadel Press, Secaucus, NJ.

Brunel, I., 1870, The life of Isambard Kingdom Brunel, civil engineer, Longman's, Green, and Co., London.

Burn, W., 1964, The age of equipoise: A study of the mid-Victorian generation, Allan \& Unwin, London.

Byrn, E., 1900, The progress of invention in the nineteenth century, Munn \& Co., New York, viewed 30 May 2016, from http://freepages.rootsweb.ancestry. com/ wakefield/history/41538-h/41538-h.htm\#CHAPTER_XXVII

Carlyle, T., 1841, On Heroes, Hero-Worship, \&The Heroic in History, James Fraser, London.

City of London, n.d., 'All change at Bank', viewed 29 June 2016, from https://www. cityoflondon.gov.uk/services/transport-and-streets/traffic-management/Pages/ Bank.aspx

Clark, C., 1799, Observations on the intended tunnel beneath the river Thames showing the many defects in the present state of that projection, Gravesend.

Copperthwaite, W., 1906, Tunnel shields and the use of compressed air in subaqueous works, D. Van Nostrand Company, New York.

Cruickshank, D., 1995, 'The great bore in its time - A forgotten gem in ours', Independent, 22 March, London, viewed 14 July 2016, from http://www. independent.co.uk/arts-entertainment/the-great-bore-in-its-time-a-forgottengem-in-ours-1612274.html

De Amicis, E., 2007 [1873], Memories of London, transl. S. Parkin, Alma Classics, London.

De Amicis, E., 1873, 'Tower subway extract', transl. Anon., viewed 13 July 2016, from http://www.victorianlondon.org/thames/towersubway.htm

Dickens, C., 1879, Dickens's dictionary of London, Old House Books, London.

Drew, W., 1852, Glimpses and gatherings during a voyage and visit to London and the great exhibition in the summer of 1851, Homan \& Manly, Augusta.

Drinker, H., 1878, Tunneling, explosive compounds and rockdrills, John Wiley and Sons, New York.

Fennell, D., 1988, Investigation into the King's cross underground fire, The Department of Transport, London.

Grace's Guide to British Industrial History, viewed 14 July 2016, http://www. gracesguide.co.uk/James_Henry_Greathead

Greathead, J., 1896, The City and South London railway; with some remarks upon subaqueous tunnelling by shield and compressed air, ed. J. Forrest, The Institution of Civil Engineers, London.

Harris, S., 2016, 'Brunel's Thames Tunnel Grand Entrance Hall Reopens to the Public as Performance Space', HuffPost: United Kingdom, 14 April 2016, viewed 14 July 2016, from http://www.huffingtonpost.co.uk/entry/brunel-thames-tunnelgrand-entrance-hall-reopens_uk_570e55b8e4b00ed33e06b703

Hawthorne, N., 1997, The English notebooks 1853-1856, ed. T. Woodson \& B. Ellis, Centenary Edition, vol. 21, Ohio State UP, Columbus, $\mathrm{OH}$.

Hughes-Hallett, L., 2005, Heroes: Saviours, traitors and supermen; A history of heroworship, Knopf, New York.

Institution of Civil Engineers, 1848 [1837], Minutes of proceedings of the Institution of Civil Engineers ... for the session of 1837, vol. 1, Institution of Civil Engineers, London.

Law, H., 1845-1846, 'A memoir of the several operations, and the construction, of the Thames tunnel', Weale's quarterly papers on engineering, London, vol. $3, \mathrm{pp}$. 1-25; vol. 5, pp. 1-86.

Lydon, R., 2012, 'The eighth wonder of the world: How might access for vehicles have prevented the failure of the Thames Tunnel 1843-1865', Working Papers 171/12 Department of Economic History, London School of Economics, London, viewed 13 July 2016, from http://www.lse.ac.uk/economicHistory/workingPapers/2012/ WP171.pdf
Mather, J., 2004, 200 years of British hydrogeology, Geological Society of London, London.

Macleod, C., 2007, Heroes of invention: Technology, liberalism and British identity, 1750-1914, Cambridge UP, Cambridge.

Mitronatsios, P., Tsipotas, D., Shortsianitis, A. \& Mastroyiannis, G., 2010, 'A method for the consolidation of mural substrates and mortars with enemas, using mechanical pump apparatus', paper presented at Conservation Science 2010 conference, Thessaloniki, 26-28 November, viewed 14 July 2016, from https:// www.academia.edu/802582

Nash, M., 1987, The Settler handbook: A new list of the 1820 Settlers, Chameleon Press, Diep River, Cape Town.

Pedroche, B., 2013, Working the London underground: From 1863-2013, The History Press, Stroud.

Pliny the Elder, AD 77-79 [1962], Natural History, Volume X: Books 36-37, transl. D. E. Eichholz, Loeb Classical Library 419, Harvard University Press, Cambridge, MA.

Ruskin, J., 1871 [1903-1912], Fors Clavigera. The works of John Ruskin, eds. E.T. Cook \& A. Wedderburn. vol. 30. Longmans, Green, and Co., London.

Shakespeare, W., 1987 [1610-1611], The tempest, Oxford University Press, Oxford.

Stewart, J. \& Cohen, J., 1997, Figments of reality, Cambridge UP, Cambridge.

Tugnutt, T. 'James Greathead statue', London remembers, viewed 19 April 2016, from http://www.londonremembers.com/memorials/james-greathead-statue

'Tunnel under the River Thames', The Mirror, London, 24 May 1824, vol. 84, p. 322.

Vail, A., 2014, 'Greathead Tunnelling Shield at Bank Station', viewed 14 July 2016 http://www.ipernity.com/doc/avail/31366645

Vogel, R., 1966, Tunnel engineering: A museum treatment, Smithsonian Institution, Washington, DC, viewed 19 April 2016, from http://www.ajhw.co.uk/books/ book449/book449.html

Wahlstrom, E., 1973, Tunnelling in rock, Elsevier, Amsterdam.

Wikipedia, n.d.a, 'Royal Exchange, London, UK' viewed 14 July 2016, from https:// commons. wikimedia.org/w/index.php?curid=35681312

Wikipedia, n.d.b, 'Statue of James Henry Greathead outside The Royal Exchange Surprisingly only erected in 1994', viewed 14 July 2016, from https://en.wikipedia. org/wiki/File\%3AStatue of James Henry Greathead_outside_The Royal Exchange_-_geograph.org.uk_-_887035.jpg

Wikipedia, n.d.c, 'Close-up image of the J. H. Greathead statue', viewed 14 July 2016, from https://commons. wikimedia.org/w/index.php?curid=30753052

Wikipedia, n.d.d, 'James Henry Greathead (1844-1896), civil and railway engineer', viewed 14 July 2016, from https://commons.wikimedia.org/wiki/File:James Henry_Greathead.png

Wikipedia, n.d.e, 'Inscription on the plinth of J. H. Greathead', viewed 14 July 2016, from https://commons.wikimedia.org/w/index.php?curid=30753050

Wikipedia, n.d.f, 'Diagram of the tunnelling shield used to construct the Thames Tunnel, London', viewed 14 July 2016, from https://commons.wikimedia.org/w/ index.php?curid $=661928$

Wikipedia, n.d.g, 'A scale model of Marc Brunel's tunnelling shield in the Brune Museum at Rotherhithe (Photo: Duncan Kimball)', viewed 14 July 2016, from https://commons. wikimedia.org/w/index. php?curid=8375450

Wikipedia, n.d.h, 'Inside the Thames Tunnel During Construction, 1830', viewed 14 July 2016, from https://commons.wikimedia.org/wiki/File:Thames_tunnel construction_1830.jpg

Wikipedia, n.d.i, 'Tunneleingang on the river side of Rotherhithe', viewed 14 July 2016, from https://de.wikipedia.org/wiki/Datei:Illustrirte_Zeitung (1843)_01_006_2_Tunneleingang_an_der_Flu\%C3\%9Fseite_von_Rotherhithe. PNG

Wikipedia, n.d.j, 'Thames Tunnel 1840', viewed 14 July 2016, from https://commons. wikimedia.org/wiki/File:Thamestunnel1840.jpg

Wikipedia, n.d.k, 'Thames Tunnel shaft', viewed 14 July 2016, from https://en. wikipedia.org/wiki/File:Thamestunnelshaft.gif

Wikipedia, n.d.I, 'Location of the Tower Subway, London. Extracted from Reynolds' Shilling Map, 1895', viewed 14 July 2016, from https://commons.wikimedia.org/ wiki/File:Tower_subway_map.gif

Wikipedia, n.d.m, 'Tower Subway, northern entrance kiosk', viewed 14 July 2016, from https://en.wikipedia.org/wiki/File:Tower_subway_1.jpg

Wikipedia, n.d.n, 'Tower subway carriage', viewed 14 July 2016, from https:// commons. wikimedia.org/w/index. php?curid $=299712$

Wikipedia, n.d.o, 'Constructing the Metropolitan Railway', viewed 14 July 2016, from https://en.wikipedia.org/wiki/File:Constructing_the_Metropolitan_Railway.png

Wikipedia, n.d.p, 'The Greathead tunnelling shield designed by James Henry Greathead in use in the construction of the Waterloo \& City Railway, London', viewed 14 July 2016, from https://commons.wikimedia.org/w/index.php?curid= 27820364

Wikipedia, n.d.q, 'Electric railway train', viewed 14 July 2016, from https://commons. wikimedia.org/w/index.php?curid $=300770$

Wikipedia, n.d.r, 'The interior of a C\&SLR padded cell carriage', viewed 14 July 2016 from https://commons.wikimedia.org/wiki/File:C\%26SLR.jpg

West, G., 2005, Innovation and the rise of the tunnelling industry, Cambridge UP, Cambridge. 